\title{
Kokumi Taste Active Peptides Modulate Salt and Umami Taste
}

\author{
Mee-Ra Rhyu ${ }^{1}$ * , Ah-Young Song ${ }^{1}$, Eun-Young Kim ${ }^{1}$, Hee-Jin Son ${ }^{1}$, Yiseul Kim ${ }^{1}$, \\ Shobha Mummalaneni ${ }^{2}$, Jie Qian ${ }^{2}$, John R. Grider ${ }^{2}(D)$ and Vijay Lyall ${ }^{2, *}$ \\ 1 Korea Food Research Institute, Wanju-gun, Jeollabuk-do 55365, Korea; ahsong47@naver.com (A.-Y.S.); \\ keykos@naver.com (E.-Y.K.); thsgmlwls77@naver.com (H.-J.S.); kimys@kfri.re.kr (Y.K.) \\ 2 Department of Physiology and Biophysics, Virginia Commonwealth University, Richmond, VA 23298, USA; \\ shobha.mummalaneni@vcuhealth.org (S.M.); jie.qian@vcuhealth.org (J.Q.); \\ john.grider@vcuhealth.org (J.R.G.) \\ * Correspondence: mrrhyu@kfri.re.kr (M.-R.R.); vijay.lyall@vcuhealth.org (V.L.); \\ Tel.: +82-63-219-9268 (M.-R.R.); +1-(804)-828-9759 (V.L.); \\ Fax: +82-63-219-9876 (M.-R.R.); +1-(804)-827-0947 (V.L.)
}

Received: 31 March 2020; Accepted: 22 April 2020; Published: 24 April 2020

check for updates

\begin{abstract}
Kokumi taste substances exemplified by $\gamma$-glutamyl peptides and Maillard Peptides modulate salt and umami tastes. However, the underlying mechanism for their action has not been delineated. Here, we investigated the effects of a kokumi taste active and inactive peptide fraction (500-10,000 Da) isolated from mature $\left(\mathrm{FII}_{\mathrm{m}}\right)$ and immature $\left(\mathrm{FII}_{\mathrm{im}}\right)$ Ganjang, a typical Korean soy sauce, on salt and umami taste responses in humans and rodents. Only $\mathrm{FII}_{\mathrm{m}}(0.1-1.0 \%)$ produced a biphasic effect in rat chorda tympani (CT) taste nerve responses to lingual stimulation with $100 \mathrm{mM}$ $\mathrm{NaCl}+5 \mu \mathrm{M}$ benzamil, a specific epithelial $\mathrm{Na}^{+}$channel blocker. Both elevated temperature $\left(42{ }^{\circ} \mathrm{C}\right)$ and $\mathrm{FII}_{\mathrm{m}}$ produced synergistic effects on the $\mathrm{NaCl}+$ benzamil $\mathrm{CT}$ response. At $0.5 \% \mathrm{FII}_{\mathrm{m}}$ produced the maximum increase in rat $\mathrm{CT}$ response to $\mathrm{NaCl}$ + benzamil, and enhanced salt taste intensity in human subjects. At $2.5 \% \mathrm{FII}_{\mathrm{m}}$ enhanced rat $\mathrm{CT}$ response to glutamate that was equivalent to the enhancement observed with $1 \mathrm{mM}$ IMP. In human subjects, $0.3 \% \mathrm{FII}_{\mathrm{m}}$ produced enhancement of umami taste. These results suggest that $\mathrm{FII}_{\mathrm{m}}$ modulates amiloride-insensitive salt taste and umami taste at different concentration ranges in rats and humans.
\end{abstract}

Keywords: Korean soy sauce; kokumi; umami; salty; chorda tympani; amiloride-insensitive salt taste pathway

\section{Introduction}

Mammals use G-protein-coupled receptors (GPCRs) expressed in Type II taste receptor cells (TRCs) to detect bitter, sweet, and umami taste stimuli. While amiloride-sensitive salt taste is detected by Type 1 cells expressing epithelial $\mathrm{Na}^{+}$channels, Type II and Type III cells mediate amiloride-insensitive salt taste. Otopetrin-1 proton selective channel expressed in Type III TRCs detects sour taste stimuli [1-6]. Much progress has been made in the identification of taste receptors and the downstream signalling mechanisms involved in the transduction of salty, sour, sweet, bitter and umami taste qualities. However, psychophysical, neural, and cellular studies have long suggested that cell to cell interactions within taste buds and interactions between different taste receptors enhance or suppress taste responses $[7,8]$. The synergism between monosodium glutamate (MSG) and 5'-ribonucleotides, a distinct characteristic of umami taste, is an example of a binary taste interaction between agonists [9,10]. Additionally, umami peptides modulate bitterness by interfering with ligand binding to the human bitter taste receptor TAS2R16 [11]. Interactions between non-tastants and tastants can also modulate taste intensity. 
SE-1, a sweet receptor positive allosteric modulator, binds to the sweet receptor without activating it, but does so in a manner that causes the orthogonal ligands to bind with higher affinity [12,13].

Kokumi taste has the characteristics of enhancing continuity, thickness, and mouthfeel, and was first observed in an aqueous extract of garlic in an umami solution. Kokumi produces its effect despite minimally eliciting any taste on its own [14]. Sulfur-containing compounds and their $\gamma$-glutamyl peptides, including $\gamma$-Glu-Cys-Gly (GSH) were suggested to be kokumi-active substances [14-17]. Because GSH was identified as an endogenous modulator of the calcium-sensing receptor, which participates in calcium homeostasis in the body [18], identification of GSH as an active component suggests the involvement of calcium-sensing receptor in kokumi perception [19]. Subsequent sensory analyses using various extracellular calcium-sensing receptor agonists have shown that kokumi did have a taste-enhancing effect on sweet, salty, and umami taste [19]. Not only does the $\gamma$-glutamyl peptide elicit kokumi taste, but the Maillard [20] reacted peptides (MRPs), which are gradually formed by longer maturation of Korean soy sauce, Ganjang (JGN), have been suggested to play a role in the kokumi taste in humans [21]. JGN is generally stored at ambient conditions for a year, and for up to four years or more to attain full maturity. The taste characteristics of kokumi increase as the maturation progresses.

Salt taste is detected by at least two receptor-mediated pathways. One pathway is $\mathrm{Na}^{+}$specific and involves $\mathrm{Na}^{+}$influx into TRCs that express amiloride- and benzamil (Bz)-sensitive epithelial $\mathrm{Na}^{+}$ channels (ENaCs) [22,23]. The second pathway is amiloride-insensitive and is cation nonselective, and does not discriminate between $\mathrm{Na}^{+}, \mathrm{K}^{+}$and $\mathrm{NH}_{4}{ }^{+}$salts. The contribution of these two pathways varies in different taste receptive fields. Approximately $65 \%$ of TRCs in the fungiform taste buds exhibit functional ENaCs, 35\% of TRCs in foliate taste buds are amiloride-sensitive, while TRCs in the circumvallate are completely amiloride-insensitive, and do not seem to express functional ENaCs [24]. Although at present the identity of the amiloride-insensitive $\mathrm{Na}^{+}$pathways in TRCs remains elusive, the amiloride- and Bz-insensitive salt taste receptors are the predominant transducers of salt taste in humans [25-27].

Investigations conducted using the Maillard reaction between peptides (1000-5000 Da) isolated from soy protein hydrolysate and xylose (Xyl-MRPs) have been known to enhance umami, continuity, and mouthfeel in umami solution, support the notion that MRPs are another class of kokumi substances [28]. Interestingly, Xyl-MRPs not only modulate umami taste, but also modulate salt taste. The effect of Xyl-MRPs on salt taste is observed at much lower concentrations than those that increase the umami taste [27]. Over a range of concentrations, Xyl-MRPs [27,29] reversibly enhanced the Bz-insensitive $\mathrm{NaCl}$ chorda tympani (CT) taste nerve response in rodents, whereas, at high concentrations, they inhibited the Bz-insensitive $\mathrm{NaCl} \mathrm{CT}$ response. The effect of Xyl-MRPs on the Bz-insensitive $\mathrm{NaCl}$ CT responses were transient receptor potential vanilloid 1 (TRPV1)-dependent. In human sensory evaluation, at low salt concentrations, galacturonic acid MRPs (GalA-MRPs) [27] enhanced human salt taste perception. These data suggest that, in both rodents and humans, MRPs induce changes in amiloride-insensitive salt taste and umami taste.

In this paper, we investigated the effects of a naturally occurring MRPs fraction (500-10,000 Da, FII) isolated from mature ( $\mathrm{FII}_{\mathrm{m}} ; 4$-year old) and immature (FII $\mathrm{im}_{\text {; }}$ 1-year old) JGN on salty and umami taste responses in rodents and human subjects. Effects of $\mathrm{FII}_{\mathrm{m}}$ and $\mathrm{FII}_{\mathrm{im}}$ were investigated on the Bz-insensitive $\mathrm{NaCl}$ CT responses and their interactions with TRPV1 modulators, and glutamate $\mathrm{CT}$ responses in rats. Effects of $\mathrm{FII}_{\mathrm{m}}$ and $\mathrm{FII}_{\mathrm{im}}$ were investigated on behavioral responses to $\mathrm{NaCl}$ in $\mathrm{C} 57 \mathrm{BL} / 6$ mice, and on the sensory evaluation of salty and umami tastes in human subjects. Our results demonstrate that $\mathrm{FII}_{\mathrm{m}}$ produces concentration-dependent biphasic effects on amiloride-insensitive neural and behavioral responses to $\mathrm{NaCl}$ in rodents. Above the concentrations that modulate salty taste, FII $_{m}$ enhanced CT responses to glutamate. In human subjects, FII $_{m}$ produced concentration-dependent biphasic effects on salt taste perception and at higher concentrations enhanced umami taste. These results suggest that $\mathrm{FII}_{\mathrm{m}}$ modulates salty and umami taste in rodents and humans via similar mechanisms. 


\section{Materials and Methods}

\subsection{Isolation of $F I I_{m}$ and $F I I_{i m}$ from JGN}

FII fraction containing MRPs of molecular weight (MW) ranging between 500 and 10,000 Da was isolated from immature ( $\mathrm{FII}_{\text {im }}$; 1-year old) and mature ( $\mathrm{FII}_{\mathrm{m}}$; 4-year old) JGN with an ultra-filtration unit (Model 840, Amicon Inc., Beverly MA, USA) using YM-10 (MW cutoff 10,000 Da) and YC-05 (MW cutoff $500 \mathrm{Da}$ ) membranes (Millipore Co., Bedford, MA, USA) at $2-4{ }^{\circ} \mathrm{C}$ under $\mathrm{N}_{2}$ pressure. Each fraction was lyophilized and stored in a desiccated freezer at $-20{ }^{\circ} \mathrm{C}$ until use. $\mathrm{FII}_{\mathrm{m}}$ was further separated using YM5, YM3 or YM1 Millipore membranes that had a cut off MW of 5000, 3000 and 1000 Da, respectively. These fractions were: FII $\mathrm{ma}_{\mathrm{ma}}$ (M00-1000 Da), FII mb (MW 1000-3000 Da), FII $\mathrm{mc}_{\mathrm{mc}}$ (MW 3000-5000 Da) and $\mathrm{FII}_{\mathrm{md}}$ (MW 5000-10,000 Da). FII $\mathrm{m}$ and $\mathrm{FII}_{\mathrm{im}}$ are the unfractionated MRPs and $\mathrm{FII}_{\mathrm{m}(\mathrm{a}-\mathrm{d})}$ are the sub-fractions of different molecular weight. Successive column chromatography was performed with $\mathrm{FII}_{\mathrm{m}}$ to obtain aromatic, basic, acidic, and neutral conjugated peptide fractions using activated charcoal (60 $\mathrm{cm}$ long and $4.0 \mathrm{~cm}$ I.D.; Junsei Chemical Co. Ltd., Tokyo, Japan), cation-exchanger $(60 \mathrm{~cm}$ long and $3.0 \mathrm{~cm}$ I.D.; Amberlite IRC-50), and anion-exchanger (60 cm long and $3.0 \mathrm{~cm}$ I.D.; Amberlite IRA 400, both from Sigma Co. Ltd., St. Louis, MO, USA) [30,31].

\subsection{CT Taste Nerve Recordings}

In contrast to glossopharyngeal nerve response to $\mathrm{NaCl}$, the predominant $\mathrm{NaCl} \mathrm{CT}$ response in rodents is amiloride sensitive. However, a significant part of the $\mathrm{NaClCT}$ response is $\mathrm{Bz}$ - and amiloride insensitive across the concentration-response range of $\mathrm{NaCl}$ [32]. The identity of the amiloride-insensitive receptor presently at best remains elusive in the circumvallate taste receptive field. Our previous studies suggest that in the anterior tongue the amiloride-insensitive pathway is a non-selective cation channel that is sensitive to resiniferatoxin (RTX), N-(3-methoxyphenyl)-4-chlorocinnamide, SB-366791 (SB), capsazepine, iodo-RTX, and temperature [33,34]. We have previously investigated the effect of various salt taste modulators on the Bz-insensitive $\mathrm{NaCl} \mathrm{CT}$ response using both rats and mice $[27,29,32-36]$. To compare the results of the effects of $\mathrm{FII}_{\mathrm{m}}$ on neural responses to $\mathrm{NaCl}$ with previously published results, we monitored Bz-insensitive $\mathrm{NaCl} \mathrm{CT}$ response in rats.

Animals were housed in the Virginia Commonwealth University (VCU) animal facility in accordance with institutional guidelines. All animal protocols were approved by the Institutional Animal Care and Use Committee (IACUC \#AD20116). Female Sprague-Dawley rats (150-200 gm) were anesthetized by intraperitoneal injection of pentobarbital $(60 \mathrm{mg} / \mathrm{Kg})$ and supplemental pentobarbital $(20 \mathrm{mg} / \mathrm{Kg}$ ) was administered as necessary to maintain surgical anesthesia. The animal's corneal reflex and toe-pinch reflex were used to monitor the depth of surgical anesthesia. Body temperatures were maintained at $37^{\circ} \mathrm{C}$ with a Deltaphase Isothermal PAD (Model 39 DP: Braintree Scientific Inc. Braintree, MA, USA). The left CT nerve was exposed laterally as it exited the tympanic bulla and placed onto a $32 \mathrm{G}$ platinum/iridium wire electrode. CT responses were recorded and analyzed as described previously $[27,29,32-36]$.

The composition of rinse and $\mathrm{NaCl}$ stimulating solutions is shown in Table 1. CT responses in rats were monitored while the anterior lingual surface was stimulated first with the rinse solution (R) and then with salt solutions containing $0.1-0.5 \% \mathrm{FII}_{\mathrm{im}}, \mathrm{FII}_{\mathrm{m}}$ and $\mathrm{FII}_{\mathrm{m}}$ sub-fractions ( $\mathrm{FII}(\mathrm{a}-\mathrm{d})$ ). The $\mathrm{pH}$ of the rinse solution and the salt solutions was adjusted to 6.1. In some experiments $\mathrm{Bz}(5 \mu \mathrm{M}) \mathrm{was}$ added to salt solutions to block $\mathrm{Na}^{+}$entry into TRCs through apical epithelial Bz-sensitive ENaCs. $\mathrm{CT}$ responses were also recorded at $23^{\circ} \mathrm{C}$ and $42{ }^{\circ} \mathrm{C}$. In additional experiments we tested the effect of $\mathrm{FII}_{\mathrm{m}}$ on the CT response to MSG and MSG + $5^{\prime}$-inosine monophosphate (IMP), a specific modulator of umami taste [37]. CT responses to MSG were monitored in the presence of $\mathrm{Bz}$ to eliminate the contribution of $\mathrm{Na}^{+}$to the glutamate CT response [33] and SB $(1 \mu \mathrm{M})$, a TRPV1 blocker [38]. In CT experiments the tonic (steady-state) part of the $\mathrm{NaCl} \mathrm{CT}$ response or glutamate $\mathrm{CT}$ response was quantified and normalized to $\mathrm{CT}$ responses to $0.3 \mathrm{M} \mathrm{NH}_{4} \mathrm{Cl}$. The normalized data were reported as the mean $(\mathrm{M}) \pm$ SEM of the number of animals $(n)$. Student's t-test was employed to analyze the differences 
between sets of data. Since we are comparing the normalized CT responses to $\mathrm{NaCl}+\mathrm{Bz}$ before and after $\mathrm{FII}_{\mathrm{im}}, \mathrm{FII}_{\mathrm{m}}$ or $\mathrm{FII}_{\mathrm{m}}$ sub-fractions in the same $\mathrm{CT}$ preparation, paired t-test was used to evaluate statistical significance.

Table 1. Taste stimuli used for CT experiments.

\begin{tabular}{|c|c|c|c|}
\hline & $(\mathrm{mM})$ & Stimuli & $(\mathrm{mM})$ \\
\hline $\mathrm{R}$ & $\begin{array}{l}10 \mathrm{KCl}+10 \\
\text { HEPES }\end{array}$ & $\mathrm{NaCl}$ & $10 \mathrm{KCl}+10 \mathrm{HEPES}+100 \mathrm{NaCl}$ \\
\hline $\mathrm{R}$ & $\begin{array}{l}10 \mathrm{KCl}+10 \\
\mathrm{HEPES}\end{array}$ & $\mathrm{NaCl}+\mathrm{Bz}$ & $10 \mathrm{KCl}+10 \mathrm{HEPES}+100 \mathrm{NaCl}+0.005 \mathrm{Bz}$ \\
\hline $\mathrm{R}$ & $\begin{array}{l}10 \mathrm{KCl}+10 \\
\mathrm{HEPES}\end{array}$ & $\mathrm{NaCl}+\mathrm{Bz}+\mathrm{RTX}$ & $\begin{array}{c}10 \mathrm{KCl}+10 \mathrm{HEPES}+100 \mathrm{NaCl}+0.005 \mathrm{Bz}+\mathrm{RTX} \\
(0-0.01)\end{array}$ \\
\hline $\mathrm{R}$ & $\begin{array}{l}10 \mathrm{KCl}+10 \\
\text { HEPES }\end{array}$ & $\begin{array}{l}\mathrm{NaCl}+\mathrm{Bz}+\mathrm{FII} \text { or } \\
\text { sub-fractions }\end{array}$ & $\begin{array}{c}10 \mathrm{KCl}+10 \mathrm{HEPES}+100 \mathrm{NaCl}+0.005 \mathrm{Bz}+\mathrm{FII} \\
\text { or sub-fractions }\end{array}$ \\
\hline $\mathrm{R}$ & $\begin{array}{l}10 \mathrm{KCl}+10 \\
\text { HEPES }\end{array}$ & $\mathrm{NaCl}+\mathrm{SB}$ & $10 \mathrm{KCl}+10 \mathrm{HEPES}+100 \mathrm{NaCl}+0.001 \mathrm{SB}$ \\
\hline $\mathrm{R}$ & $\begin{array}{l}10 \mathrm{KCl}+10 \\
\text { HEPES }\end{array}$ & $\mathrm{NaCl}+\mathrm{SB}+\mathrm{FII}$ & $\begin{array}{c}10 \mathrm{KCl}+10 \mathrm{HEPES}+100 \mathrm{NaCl}+0.001 \mathrm{SB}+\mathrm{FII} \\
\text { or sub-fractions) }\end{array}$ \\
\hline $\mathrm{R}$ & $\begin{array}{l}10 \mathrm{KCl}+10 \\
\text { HEPES }\end{array}$ & $\mathrm{N}+\mathrm{Bz}+\mathrm{SB}+\mathrm{FII}$ & $\begin{array}{c}10 \mathrm{KCl}+10 \mathrm{HEPES}+100 \mathrm{NaCl}+0.005 \mathrm{Bz}+0.001 \\
\mathrm{SB}+\mathrm{FII} \text { or sub-fractions }\end{array}$ \\
\hline $\mathrm{R}$ & $10 \mathrm{KCl}$ & $\mathrm{MSG}+\mathrm{Bz}+\mathrm{SB}$ & $10 \mathrm{KCl}+100 \mathrm{MSG}+0.005 \mathrm{Bz}+0.001 \mathrm{SB}$ \\
\hline $\mathrm{R}$ & $10 \mathrm{KCl}$ & $\mathrm{MSG}+\mathrm{Bz}+\mathrm{SB}+\mathrm{IMP}$ & $10 \mathrm{KCl}+100 \mathrm{MSG}+0.005 \mathrm{Bz}+0.001 \mathrm{SB}+1 \mathrm{IMP}$ \\
\hline $\mathrm{R}$ & $10 \mathrm{KCl}$ & $\mathrm{MSG}+\mathrm{Bz}+\mathrm{SB}+\mathrm{FII}$ & $10 \mathrm{KCl}+100 \mathrm{MSG}+0.005 \mathrm{Bz}+0.001 \mathrm{SB}+\mathrm{FII}$ \\
\hline $\mathrm{R}$ & $10 \mathrm{KCl}$ & Control-1 & $300 \mathrm{NH}_{4} \mathrm{Cl}$ \\
\hline $\mathrm{R}$ & $10 \mathrm{KCl}$ & Control-2 & $300 \mathrm{NaCl}$ \\
\hline
\end{tabular}

4-(2-Hydroxyethyl)-1-piperazine ethanesulfonic acid (HEPES) was used to buffer the $\mathrm{pH}$ of rinse and salt stimuli at $\mathrm{pH}$ 6.1. Bz (benzamil); RTX (resiniferatoxin); SB (SB-366791, N-(3-methoxyphenyl)-4-chlorocinnamide). All compounds were obtained from Sigma-Aldrich.

\subsection{Behavior Studies in Mice}

Rats have a high preference for $\mathrm{NaCl}$ even in the presence of $\mathrm{Bz}$ [29]. Because of already high background $\mathrm{NaCl}$ preference, small increases in $\mathrm{NaCl}$ preference are difficult to evaluate in rats. In contrast, mice demonstrate a more moderate preference for $\mathrm{NaCl}$ and small shifts in the preference curve are easily detected. Therefore, mice were used for behavioral studies. Behavioral studies were performed in WT (C57BL/6J) mice (30-40 gm) using standard two bottle/48 $\mathrm{h}$ tests [39]. Both males and females were used. The care and use of the mice followed the institutional and national guidelines, and the protocol was approved by the committee on the Ethics of Animal Experiments of the Korea Food Research Institute (Permit Number: KFRI-M-12028). Mice (63-70 days of age) were housed in separated cages and were maintained on a standard laboratory chow (Pico-Lab Rodent Diet 20-5053, PMI Feeds) and water ad libitum. The air-conditioned animal room was maintained at $22 \pm 2{ }^{\circ} \mathrm{C}$, with relative humidity of $59 \pm 1 \%$ and a $12 \mathrm{~h} \mathrm{light/dark} \mathrm{cycle} \mathrm{(light} \mathrm{period,} \mathrm{07:00-19:00} \mathrm{h).} \mathrm{Each} \mathrm{mouse}$ was tested at approximately the same time of day. Before the start of the experiment mice were given two bottles with water for 2 weeks. The experiment was started when mice were accustomed to drinking equally from 2 bottles. Mice were given a choice between two bottles, one containing water and the other a test solution in the following order: water, $30 \mathrm{mM} \mathrm{NaCl}, 80 \mathrm{mM} \mathrm{NaCl}, 100 \mathrm{mM} \mathrm{NaCl}$, $120 \mathrm{mM} \mathrm{NaCl}, 150 \mathrm{mM} \mathrm{NaCl}, 200 \mathrm{mM} \mathrm{NaCl}$ and $300 \mathrm{mM} \mathrm{NaCl}$. We also performed behavioral studies when both water and the $\mathrm{NaCl}$ solutions contained $10 \mu \mathrm{M}$ amiloride. In some experiments, mice were given a choice between water and $100 \mathrm{mM} \mathrm{NaCl}$ or between water $+10 \mu \mathrm{M}$ amiloride and $100 \mathrm{mM}$ $\mathrm{NaCl}+10 \mu \mathrm{M}$ amiloride containing varying concentrations $(0.1,0.25,0.5,0.75$, and $1.0 \%)$ of $\mathrm{FII}_{\mathrm{m}}$. 
For each $48 \mathrm{~h}$ period the mass of water versus the mass of the test solution consumed by each mouse/g BW was measured. The preference ratio for a taste stimulus was calculated as the mass of the test solution consumed $/ 48 \mathrm{~h} / \mathrm{g}$ BW divided by the mass of the total fluid intake (mass water + mass of the test solution) $/ 48 \mathrm{~h} / \mathrm{g}$ BW). The bottles containing water or the test solution were switched from left to right every day. The data were analyzed using one-sample t-tests against 0.5 , a reference value meaning indifference of the test solution with respect to the control solution.

\subsection{Human Sensory Evaluation}

All human sensory evaluation protocols were approved by the Public Institutional Review Board Designated by Ministry of Health and Welfare, South Korea. The ethic approval code is P01-202004-23-004. Each participant signed a consent form to participate in salt taste sensory evaluations. To maintain a subject's confidentiality, the personal data was coded and the taste data were analyzed off line. Previously trained panelists (men and women, ages between 25 to 37 years) with no history of basic taste disorders were recruited. The panelists washed their mouth after tasting each samples. The data was analyzed by one-way ANOVA to compare between-group differences.

\subsubsection{Salt Sensory Evaluation}

Panelists were trained to recognize salt taste intensity with reference to $0.2 \%, 0.35 \%, 0.5 \%$, and $0.7 \%$ $\mathrm{NaCl}$ solution representing a value of 2.5, 5.0, 8.5, and 15.0, respectively, using a 15-point intensity scale [40]. To evaluate the effect of $\mathrm{FII}_{\mathrm{im}}$ and $\mathrm{FII}_{\mathrm{m}}$ on salt taste, $\mathrm{FII}_{\mathrm{im}}$ or $\mathrm{FII}_{\mathrm{m}}(0-0.01 \%)$ dissolved in $0.2 \% \mathrm{NaCl}$ solution was presented to the panelists and the salt taste intensity was evaluated with reference to $0.2 \% \mathrm{NaCl}$ (intensity scale value $=2.5 ; \mathrm{R} 1$ ), and $0.35 \% \mathrm{NaCl}$ (intensity scale value $=5.0$; R2), respectively.

\subsubsection{Umami Sensory Evaluation}

According to the manufacturer's instructions, Japanese fish soup base, Hondashi (0.04 g) was dissolved in $100 \mathrm{ml}$ water. The $0.04 \%$ Hondashi fish soup base was used as a control and was given an intensity of 5 on a 10 -point intensity scale. $\mathrm{FII}_{\mathrm{m}}$ at $0.003 \%, 0.01 \%, 0.03 \%$ and $0.3 \%$ was dissolved in $0.04 \%$ Hondashi Fish soup base and their effect was evaluated on umami taste by the same trained panelists $(n=6)$. As a control, $\mathrm{FII}_{\mathrm{m}}$ was dissolved in water at $0.003 \%, 0.01 \%, 0.03 \%$ and $0.3 \%$. These concentrations of $\mathrm{FII}_{\mathrm{m}}$ were evaluated for umami taste by the same panelists $(n=6)$.

\section{Results and Discussion}

\subsection{Effect of $\mathrm{FII}_{m}$ and $\mathrm{FII}_{\text {im }}$ on the Bz-insensitive $\mathrm{NaCl}$ CT Response}

As shown in a representative CT trace (Figure 1A), adding increasing concentrations of $\mathrm{FII}_{\mathrm{m}}$ to $100 \mathrm{mM} \mathrm{NaCl}+5 \mu \mathrm{M} \mathrm{Bz}(\mathrm{NaCl}+\mathrm{Bz})$ solution (Table 1) initially produced an increase in both phasic and tonic $\mathrm{NaCl} \mathrm{CT}$ response of between $0.1 \%$ and $0.5 \%$. Above $0.5 \% \mathrm{FII}_{\mathrm{m}}$ the magnitudes of the phasic and tonic CT responses were less than their respective maximum values. In the presence of $1 \% \mathrm{FII}_{\mathrm{m}}$, the tonic CT response decreased below the $\mathrm{NaCl}+\mathrm{Bz}$ CT response in the absence of $\mathrm{FII}_{\mathrm{m}}$ (Figure $1 \mathrm{~A}$ ). The variation of the normalized mean tonic $\mathrm{NaCl}+\mathrm{Bz} \mathrm{CT}$ response plotted as a function of the log of $\mathrm{FII}_{\mathrm{m}}$ or $\mathrm{FII}_{\mathrm{im}}$ concentrations (\%) are summarized in Figure $1 \mathrm{~B}$. $\mathrm{FII}_{\mathrm{m}}$ produced a biphasic dose-response relationship for both the phasic (data not shown) and tonic (Figure $1 \mathrm{~B}$; •) $\mathrm{NaCl}+\mathrm{Bz} \mathrm{CT}$ response. The maximum increase in the mean normalized tonic CT response occurred at $0.5 \%$ of $\mathrm{FII}_{\mathrm{m}}$, an $88 \%$ increase relative to $\mathrm{NaCl}+\mathrm{Bz}$ tonic $\mathrm{CT}$ response in the absence of $\mathrm{FII}_{\mathrm{m}}$. At $1 \% \mathrm{FII}_{\mathrm{m}}$, the tonic $\mathrm{NaCl}+\mathrm{Bz}$ CT response was significantly less than the tonic CT response with $\mathrm{NaCl}+\mathrm{Bz}$ alone $(p=0.0466 ; n=3)$. Stimulating the tongue with the rinse solution $(\mathrm{R})$ containing varying concentrations of $\mathrm{FII}_{\mathrm{m}}$ elicited only transient (phasic) CT responses that were concentration-independent and were indistinguishable from the mechanical rinse artifact (data not shown). These results indicate that, at the concentrations used in these experiments, $\mathrm{FII}_{\mathrm{m}}$, by itself, is not a gustatory stimulus in the fungiform taste receptive 
field and only modulate the $\mathrm{CT}$ response in the presence of salt $(\mathrm{NaCl}+\mathrm{Bz})$. In contrast, $\mathrm{FII}_{\mathrm{im}} \mathrm{did}$ not produce any changes in either the phasic (data not shown) or the tonic CT response between $0.1 \%$ and 1\% (Figure 1B; $\bigcirc$ ). The Xyl-MRPs, GalA-MRPs, glucosamine-MRPs, and fructose-MRPs also produced biphasic effects on the Bz-insensitive $\mathrm{NaCl} \mathrm{CT}$ response with maximum increase at $0.25 \%, 0.25 \%$, $0.50 \%, 0.75 \%$ and $1 \%$, respectively [27]. This suggests that both MRPs naturally generated during longer maturation and synthesized in vitro have a common property of producing biphasic effects on the Bz-insensitive $\mathrm{NaCl}$ CT response. The potency of MRPs depends upon the reacted sugar moiety. However, at present it is not known which sugar moieties are conjugated to the peptides comprising $\mathrm{FII}_{\mathrm{m}}$. $\mathrm{FII}_{\mathrm{m}}$ is a mixture of MRPs of varying molecular weights, charge and affinity for their putative salt taste receptor(s). In comparison, $0.27 \%$ GalA-MRPs enhanced the Bz-insensitive $\mathrm{NaCl} \mathrm{CT}$ response by $101 \%$ [27], suggesting naturally occurring $\mathrm{FII}_{\mathrm{m}}$ produces effects on the $\mathrm{NaCl}+\mathrm{Bz} \mathrm{CT}$ response that are comparable to those produced by the GalA-MRPs.
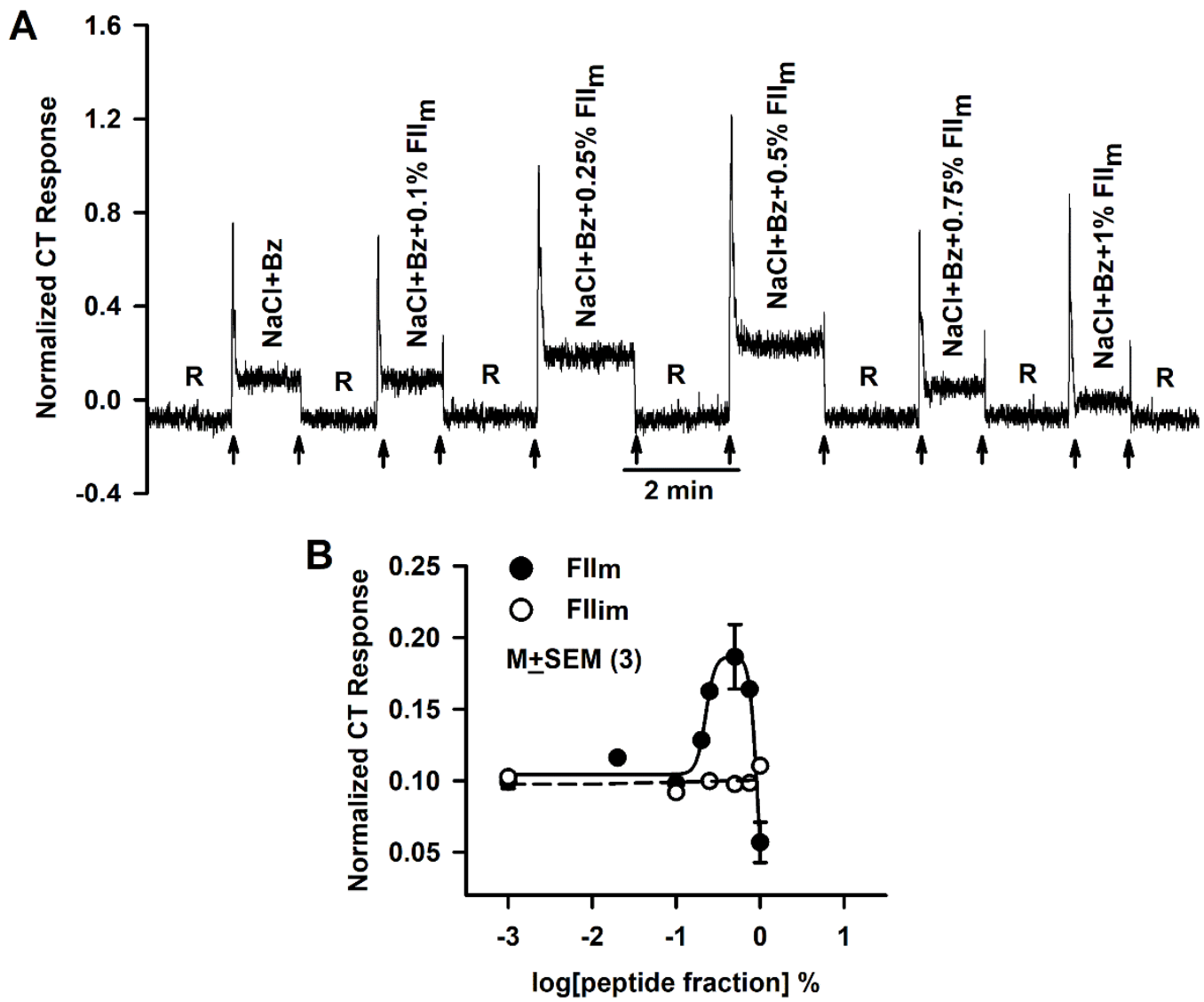

Figure 1. Effect of $\mathrm{FII}_{\mathrm{im}}$ and $\mathrm{FII}_{\mathrm{m}}$ on the benzamil (Bz)-insensitive $\mathrm{NaCl}$ chorda tympani (CT) response. (A) Shows a representative trace in which the CT responses were monitored while the rat tongue was first superfused with a rinse solution (R) and then with a stimulating solution containing $100 \mathrm{mM} \mathrm{NaCl}$ $+5 \mu \mathrm{M} \mathrm{Bz}+\mathrm{FII}_{\mathrm{m}}(0-1 \%)$ maintained at room temperature. The arrows represent the time periods when the rat tongue was superfused with $\mathrm{R}$ and the stimulating solutions. The data were normalized to the tonic response obtained with $0.3 \mathrm{M} \mathrm{NH}_{4} \mathrm{Cl}$. (B) Shows the mean normalized tonic $\mathrm{NaCl}$ CT responses in different sets of 3 rats each while their tongues were first stimulated with $\mathrm{R}$ and then with $\mathrm{NaCl}+\mathrm{Bz}$ solutions containing $0-1 \%$ of the $\mathrm{FII}_{\mathrm{m}}(\bullet)$ or $\mathrm{FII}_{\mathrm{im}}(\bigcirc)$ expressed in $\log$ units. The values are $\mathrm{M} \pm \mathrm{SEM}$ of 3 rats.

\subsection{Effect of $S B$ and $\mathrm{FII}_{m}$ on the Bz-insensitive $\mathrm{NaCl} C \mathrm{CT}$ Response}

In our previous studies, Bz-insensitive $\mathrm{NaCl} C \mathrm{CT}$ responses in rodents were inhibited by TRPV1 blockers. In addition, Bz-insensitive $\mathrm{NaCl} \mathrm{CT}$ responses were not observed in TRPV1 knockout 
mice [33]. Accordingly, in the next series of experiments we tested if $\mathrm{FII}_{\mathrm{m}}$ effects on salt responses were also sensitive to $\mathrm{SB}$, a TRPV1 blocker. Because $0.4 \%$ and $0.5 \% \mathrm{FII}_{\mathrm{m}}$ give almost equivalent $\mathrm{CT}$ responses (Figure $1 \mathrm{~B}$ ), we used $0.4 \% \mathrm{FII}_{\mathrm{m}}$ in these experiments. In mixtures containing $\mathrm{NaCl}$ $+\mathrm{Bz}+\mathrm{SB}$, the constitutive $\mathrm{NaCl}+\mathrm{Bz}$ tonic $\mathrm{CT}$ response was inhibited to the rinse baseline level (Figure 2A,C). Subsequently, stimulating the rat tongue with solutions containing $\mathrm{NaCl}+\mathrm{Bz}+\mathrm{SB}+$ $0.4 \% \mathrm{FII}_{\mathrm{m}}$ significantly inhibited the $\mathrm{CT}$ nerve response relative to $\mathrm{NaCl}+\mathrm{Bz}+0.4 \% \mathrm{FII}_{\mathrm{m}}$ (Figure $2 \mathrm{~A}$, $\mathrm{C}$; ** $p=0.0001 ; n=3$ ). These results suggest that both the constitutive amiloride- and Bz-insensitive CT response and the subsequent $\mathrm{FII}_{\mathrm{m}}$-induced increase in the $\mathrm{CT}$ response are SB-sensitive.

A

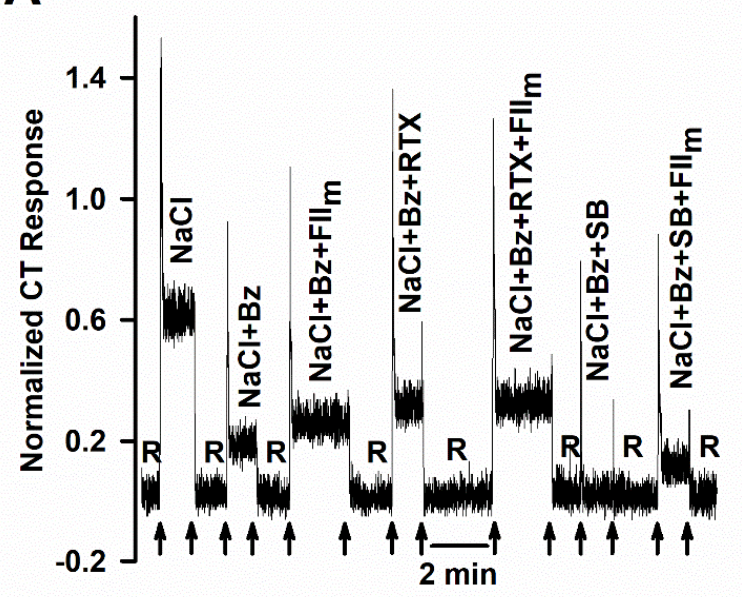

B

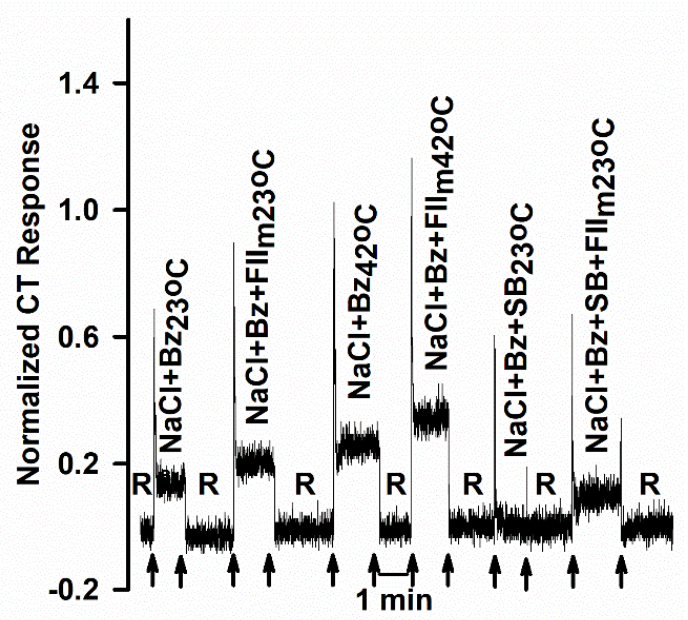

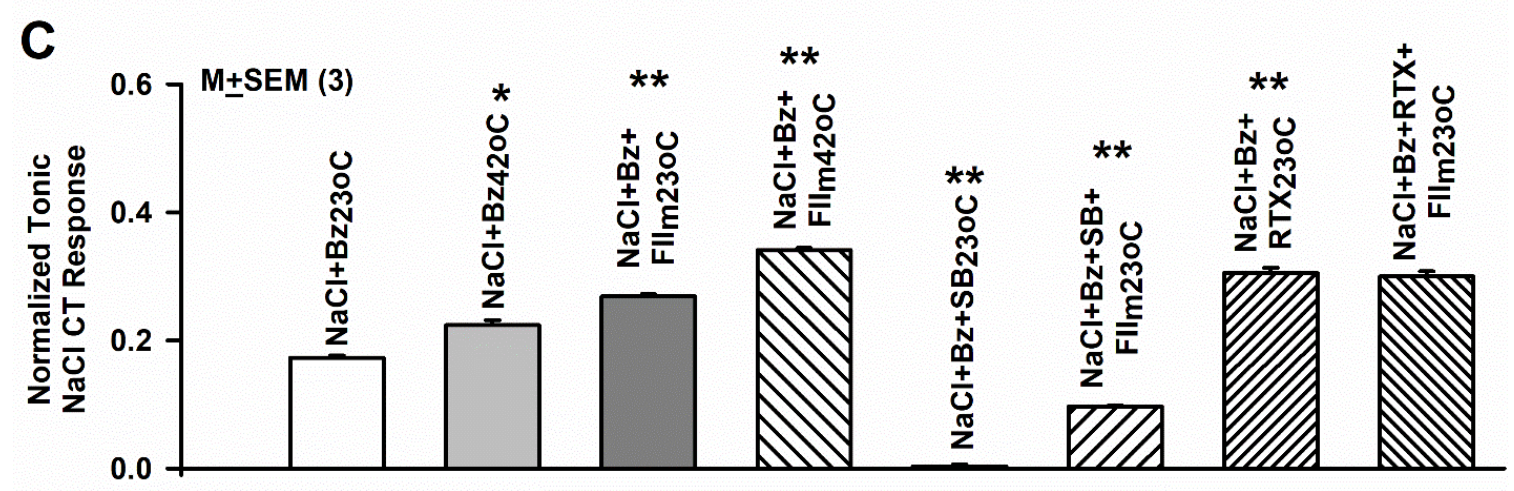

Figure 2. Effect of resiniferatoxin (RTX), SB-377791 (SB), $\mathrm{FII}_{\mathrm{m}}$ and temperature on the benzamil (Bz)-insensitive $\mathrm{NaCl}$ chorda tympani (CT) response. (A) Shows a representative $\mathrm{CT}$ trace obtained while the rat tongue was first stimulated with rinse solution (R) and then with $\mathrm{NaCl}, \mathrm{NaCl}+\mathrm{Bz}, \mathrm{NaCl}$ $+\mathrm{Bz}+0.4 \% \mathrm{FII}_{\mathrm{m}}, \mathrm{NaCl}+\mathrm{Bz}+0.25 \mu \mathrm{M} \mathrm{RTX}, \mathrm{NaCl}+\mathrm{Bz}+0.4 \% \mathrm{FII}_{\mathrm{m}}+0.25 \mu \mathrm{M} \mathrm{RTX}, \mathrm{NaCl}+\mathrm{Bz}+1 \mu \mathrm{M}$ $\mathrm{SB}$ and $\mathrm{NaCl}+\mathrm{Bz}+\mathrm{SB}+0.4 \% \mathrm{FII}_{\mathrm{m}}$ maintained at room temperature. The data were normalized to the tonic response obtained with $0.3 \mathrm{M} \mathrm{NH}_{4} \mathrm{Cl}$. The arrows represent the time periods when the rat tongues were superfused with $\mathrm{R}$ and the stimulating solutions. (B) Shows a representative $\mathrm{CT}$ trace obtained while the rat tongue was first stimulated with $\mathrm{R}$ at $23{ }^{\circ} \mathrm{C}\left(\mathrm{R}_{23}{ }^{\circ} \mathrm{C}\right)$ and then with $\mathrm{NaCl}+\mathrm{Bz}$ $\left(\mathrm{NaCl}+\mathrm{Bz}_{23}{ }^{\circ} \mathrm{C}\right), \mathrm{NaCl}+\mathrm{Bz}+0.4 \% \mathrm{FII}_{\mathrm{m}}$ at $23^{\circ} \mathrm{C}\left(\mathrm{NaCl}+\mathrm{Bz}+\mathrm{FII}_{\mathrm{m} 23}{ }^{\circ} \mathrm{C}\right), \mathrm{NaCl}+\mathrm{Bz}$ at $42{ }^{\circ} \mathrm{C}(\mathrm{NaCl}$ $\left.+\mathrm{Bz}_{42}{ }^{\circ} \mathrm{C}\right)$ and $\mathrm{NaCl}+\mathrm{Bz}+0.4 \% \mathrm{FII}_{\mathrm{m}}$ at $42{ }^{\circ} \mathrm{C}\left(\mathrm{NaCl}+\mathrm{Bz}+\mathrm{FII}_{\mathrm{m} 42}{ }^{\circ} \mathrm{C}\right)$. The trace also shows the $\mathrm{CT}$ response in the presence of $\mathrm{NaCl}+\mathrm{Bz}+\mathrm{SB}$ and $\mathrm{NaCl}+\mathrm{Bz}+\mathrm{SB}+0.4 \% \mathrm{FII}_{\mathrm{m}}$ maintained at $23^{\circ} \mathrm{C}$. The data were normalized to the tonic response obtained with $0.3 \mathrm{M} \mathrm{NH}_{4} \mathrm{Cl}$. The arrows represent the time periods when the rat tongues were superfused with $\mathrm{R}$ and the stimulating solutions. (C) Shows the $\mathrm{M} \pm \mathrm{SEM}$ normalized rat tonic $\mathrm{NaCl}+\mathrm{Bz} \mathrm{CT}$ responses at $23{ }^{\circ} \mathrm{C}$ and $42{ }^{\circ} \mathrm{C}$ in the absence and presence of $0.4 \% \mathrm{FII}_{\mathrm{m}}$. All unpaired comparisons were made with respect to the normalized value of the tonic $\mathrm{CT}$ response to $\mathrm{NaCl}+\mathrm{Bz}$ at $\left.23{ }^{\circ} \mathrm{C} .{ }^{*} p=0.0038 ;{ }^{* *} p=0.0001 ; n=3\right)$. 


\subsection{Effect of RTX and $\mathrm{FII}_{m}$ on the $\mathrm{NaCl}+\mathrm{Bz} \mathrm{CT}$ Response}

Consistent with previous studies [33,35], at room temperature $\left(23^{\circ} \mathrm{C}\right)$, RTX $(0.25 \mu \mathrm{M})$ enhanced the rat $\mathrm{NaCl}+\mathrm{Bz}$ CT response relative to $\mathrm{NaCl}+\mathrm{Bz}$ (Figure $2 \mathrm{~A}, \mathrm{C} ;{ }^{*} p=0.0001 ; n=3$ ). When the tongue was stimulated with $\mathrm{NaCl}+\mathrm{Bz}$ solutions containing both $\mathrm{RTX}(0.25 \mu \mathrm{M})$ and $\mathrm{FII}_{\mathrm{m}}(0.4 \%)$, no further increase in the magnitude of the $\mathrm{Bz}$-insensitive $\mathrm{NaCl} \mathrm{CT}$ response was observed relative to $\mathrm{NaCl}+$ $\mathrm{Bz}+\mathrm{RTX}$ (Figure 2C). These results suggest that RTX and FII $\mathrm{m}$ target the same amiloride-insensitive pathway(s). The Bz-insensitive $\mathrm{NaCl}$ taste responses are regulated by several intracellular signaling mediators. A decrease in taste cell $\mathrm{Ca}^{2+}$, activation of protein kinase $\mathrm{C}$, and inhibition of calcineurin enhanced the magnitudes of the Bz-insensitive $\mathrm{NaCl}$ CT responses in the presence of $\mathrm{RTX}$, and either minimized or completely eliminated the decrease in the CT response at RTX concentrations $>1 \mu \mathrm{M}$. In contrast, increasing taste cell $\mathrm{Ca}^{2+}$ inhibited the Bz-insensitive $\mathrm{NaCl} \mathrm{CT}$ response in the presence of RTX [41]. An increase in taste cell phosphatidylinositol 4,5-bisphosphate inhibited the control $\mathrm{NaCl}+$ $\mathrm{Bz}$ CT response and decreased its sensitivity to RTX. Alternately, a decrease in phosphatidylinositol 4,5-bisphosphate enhanced the control $\mathrm{NaCl}+\mathrm{Bz}$ CT response, increased its sensitivity to RTX stimulation, and inhibited the desensitization of the CT response at RTX concentrations $>1 \mu \mathrm{M}$ [42]. It is likely that $\mathrm{Bz}$-insensitive $\mathrm{NaCl} \mathrm{CT}$ responses in the presence of $\mathrm{FII}_{\mathrm{m}}$ are also regulated by the above intracellular modulators and are responsible for their biphasic effects on the $\mathrm{NaCl} C \mathrm{~T}$ response.

\subsection{Effect of Elevated Temperature and $\mathrm{FII}_{m}$ on the $\mathrm{NaCl}+\mathrm{Bz} \mathrm{CT}$ Response}

In our previous studies, Bz-insensitive $\mathrm{NaCl} C \mathrm{~T}$ responses in rodents were temperature dependent. In addition, temperature and modulators of the Bz-insensitive $\mathrm{NaCl} C \mathrm{~T}$ response produced additive effects on CT response $[26,33,36]$. Accordingly, we next tested the effect of elevating the temperature from $23{ }^{\circ} \mathrm{C}$ to $42{ }^{\circ} \mathrm{C}$ on the $\mathrm{CT}$ response to $\mathrm{NaCl}+\mathrm{Bz}$ and $\mathrm{NaCl}+\mathrm{Bz}+0.4 \% \mathrm{FII}_{\mathrm{m}}$. As shown in a representative $\mathrm{CT}$ recording, elevating the temperature from $23{ }^{\circ} \mathrm{C}$ to $42{ }^{\circ} \mathrm{C}$ increased the magnitude of the tonic $\mathrm{NaCl}+\mathrm{Bz} \mathrm{CT}$ response relative to $23{ }^{\circ} \mathrm{C}$ (Figure $\left.2 \mathrm{~B}\right)$. $\mathrm{FII}_{\mathrm{m}}(0.4 \%)$ further increased the $\mathrm{CT}$ response at $23{ }^{\circ} \mathrm{C}$ and $42{ }^{\circ} \mathrm{C}$ (Figure 2B). The mean tonic $\mathrm{NaCl}+\mathrm{Bz} \mathrm{CT}$ response at $23{ }^{\circ} \mathrm{C}$ (Figure 2C) was significantly enhanced by increasing the temperature to $42{ }^{\circ} \mathrm{C}\left({ }^{*} p=0.0039\right)$ and by the addition of $0.4 \% \mathrm{FII}_{\mathrm{m}}$ (Figure $2 \mathrm{C} ;{ }^{* *} p=0.0001 ; n=3$ ). These results show that elevated temperature and $\mathrm{FII}_{\mathrm{m}}$ produce additive effects on the amiloride-insensitive $\mathrm{NaCl} \mathrm{CT}$ response.

\subsection{Effect of $\mathrm{FII}_{m}$ sub-fractions of Different Molecular Weights $\left(F I I_{m(a-d)}\right)$ on the $\mathrm{NaCl}+\mathrm{Bz} C T$ Response}

$\mathrm{FII}_{\mathrm{m}}$ was further separated into four sub-fractions of varying molecular weights: $\mathrm{FII}_{\mathrm{ma}}$ (500-1000 Da), FII mb (1000-3000 Da), FII mc (3000-5000 Da) and FII md (5000-10,000 Da). As shown in representative $\mathrm{CT}$ recordings in Figs. $3 \mathrm{~A}$ and $3 \mathrm{~B}$, the relationship between varying concentrations of $\mathrm{FII}_{\mathrm{ma}}$ and $\mathrm{FII}_{\mathrm{mc}}$ and the magnitude of $\mathrm{NaCl}+\mathrm{Bz} \mathrm{CT}$ response was shifted to the right on the concentration axis relative to $\mathrm{FII}_{\mathrm{m}}$ (Figure $1 \mathrm{~A}$ ). The relationships between varying concentrations of $\mathrm{FII}_{\mathrm{ma}}, \mathrm{FII}_{\mathrm{mb}}, \mathrm{FII}_{\mathrm{mc}}$ and $\mathrm{FII}_{\mathrm{md}}$ and the corresponding mean normalized tonic $\mathrm{NaCl}+\mathrm{Bz} \mathrm{CT}$ response

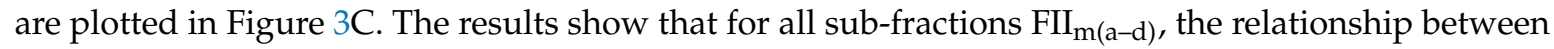
their concentrations and the magnitude of tonic $\mathrm{NaCl}+\mathrm{Bz} \mathrm{CT}$ response is shifted to the right on the concentration axis relative to $\mathrm{FII}_{\mathrm{m}}$. $\mathrm{FII}_{\text {ma }}$ produced the maximum increase in the $\mathrm{NaCl}+\mathrm{Bz}$ tonic CT response at a concentration between 1.5 and $2.5 \%$ (Figure 3C; $\diamond$ ). This concentration is significantly higher than the concentration at which $\mathrm{FII}_{\mathrm{m}}$ produced the maximum increase in the $\mathrm{NaCl}+\mathrm{Bz}$ CT response $\left(0.5 \%\right.$; Figure 1B). These results suggest that $\mathrm{FII}_{\mathrm{m}}$ fraction is composed of MRPs of varying molecular weights that differ in their affinity and potency in modulating the putative amiloride-insensitive salt taste pathway(s). 

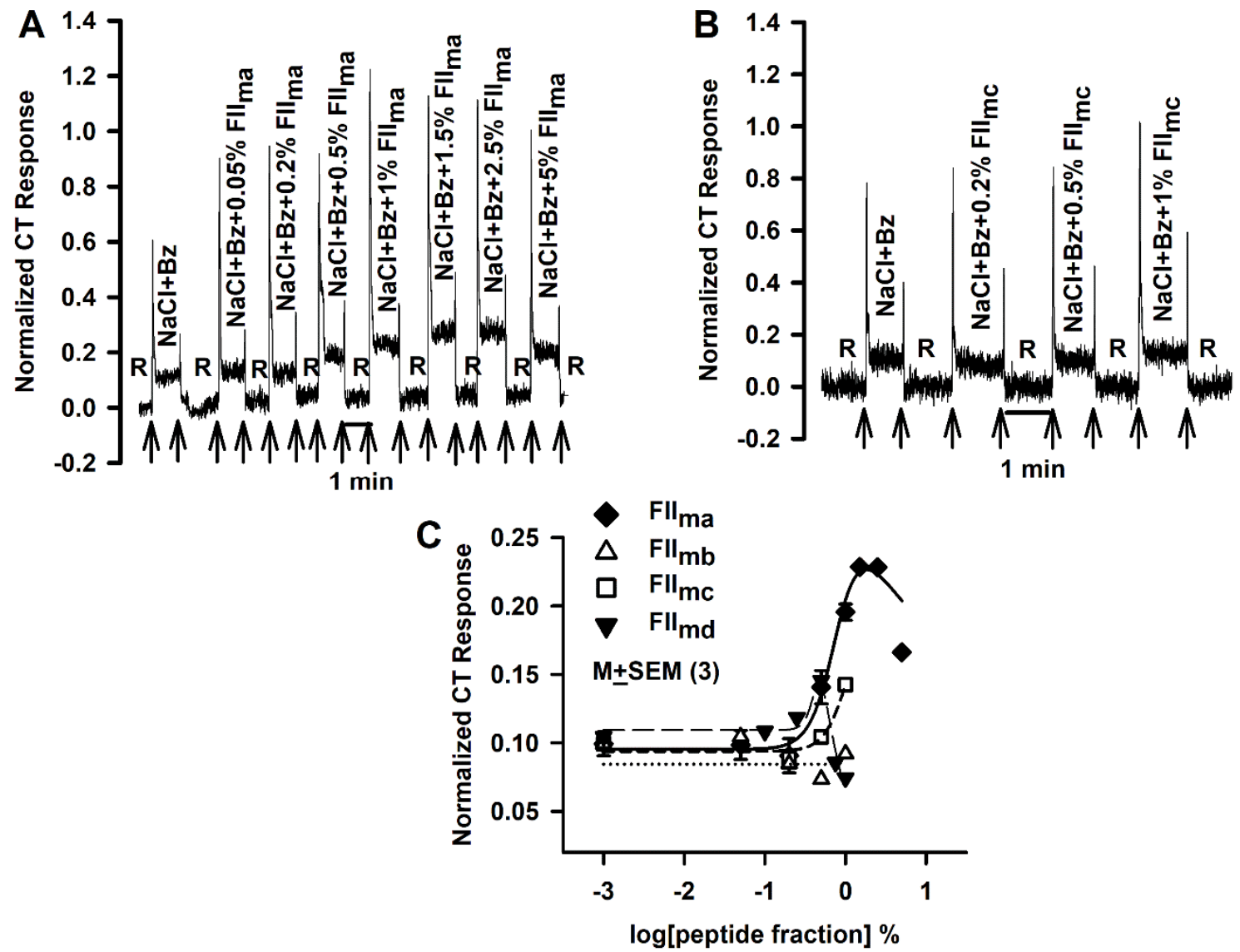

Figure 3. Effects of $\mathrm{FII}_{\mathrm{m}}$ sub-fractions $\left(\mathrm{FII}_{\mathrm{m}(\mathrm{a}-\mathrm{d})}\right)$ on the benzamil (Bz)-insensitive $\mathrm{NaCl}$ chorda tympani (CT) response. Representative CT responses showing the effect of adding varying concentrations of FII $m$ sub-fractions FII ${ }_{m a}(500-1000 \mathrm{Da})(\mathbf{A})$ and FII $_{\mathrm{mc}}(1000-3000 \mathrm{Da})(\mathbf{B})$ on the rat CT responses to $\mathrm{NaCl}+\mathrm{Bz}$. The arrows represent the time period when the tongue was superfused with the rinse and stimulating solutions. In each rat the data were normalized to the tonic response obtained with $0.3 \mathrm{M}$ $\mathrm{NH}_{4} \mathrm{Cl}$. (C) Shows the mean normalized tonic $\mathrm{NaCl} \mathrm{CT}$ responses in different sets of 3 rats each while their tongues were first stimulated with $\mathrm{R}$ and then with $\mathrm{NaCl}+\mathrm{Bz}$ solutions containing $0-1 \%$ of the four $\mathrm{FII}_{\mathrm{m}}$ sub-fractions in $\log$ units. The values are $\mathrm{M} \pm \mathrm{SEM}$ of 3 rats in each group. In each case the data were fitted to Equation (4).

\subsection{Effect of FII $m$ sub-fractions (Neutral, Acidic, Basic and Aromatic) on the $\mathrm{NaCl}+\mathrm{Bz} \mathrm{CT}$ Response}

$\mathrm{FII}_{\mathrm{m}}$ was further separated into neutral, acidic, basic and aromatic sub-fractions. Since the relationships between varying concentrations of the neutral, acidic and basic fractions and the magnitude of the tonic $\mathrm{NaCl}+\mathrm{Bz} \mathrm{CT}$ response were very similar in individual rats, the data from these three fractions were combined and are plotted in Figure $4 \mathrm{~A}(\mathbf{\Delta})$. In all three fractions, the relationship between their concentrations and the magnitude of the mean normalized tonic $\mathrm{NaCl} C \mathrm{~T}$ response was shifted to the right on the concentration axis relative to $\mathrm{FII}_{\mathrm{m}}$ (Figure $4 \mathrm{~A} ; \bullet$ ). In contrast, the aromatic fraction produced a biphasic response in the $\mathrm{NaCl}+\mathrm{Bz} C \mathrm{CT}$ response with a very sharp-peak at $0.75 \%$ (Figure $4 \mathrm{~A} ; \bigcirc$ ). These results further suggest that $\mathrm{FII}_{\mathrm{m}}$ is composed of neutral, acidic, basic and aromatic MRPs that show varying degrees of potency and affinity for modulating the putative amiloride-insensitive salt taste pathway(s). It is interesting to note that relative to control $(\mathrm{NaCl}+\mathrm{Bz})$, $0.5 \% \mathrm{FII}_{\mathrm{m}}$ (Figure $1 \mathrm{~A}$ ) produced an equivalent maximum increase in the tonic $\mathrm{NaCl}+\mathrm{Bz} \mathrm{CT}$ response as $1 \mu \mathrm{M}$ RTX (Figure $4 \mathrm{~B}$ ). 


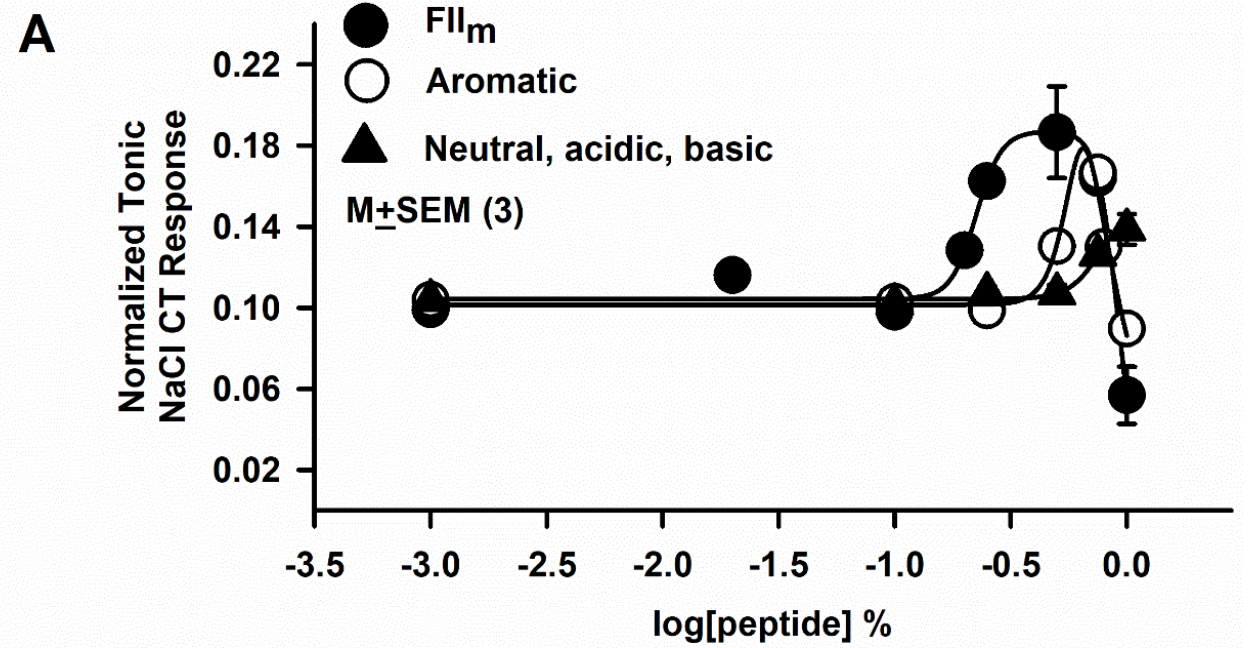

B

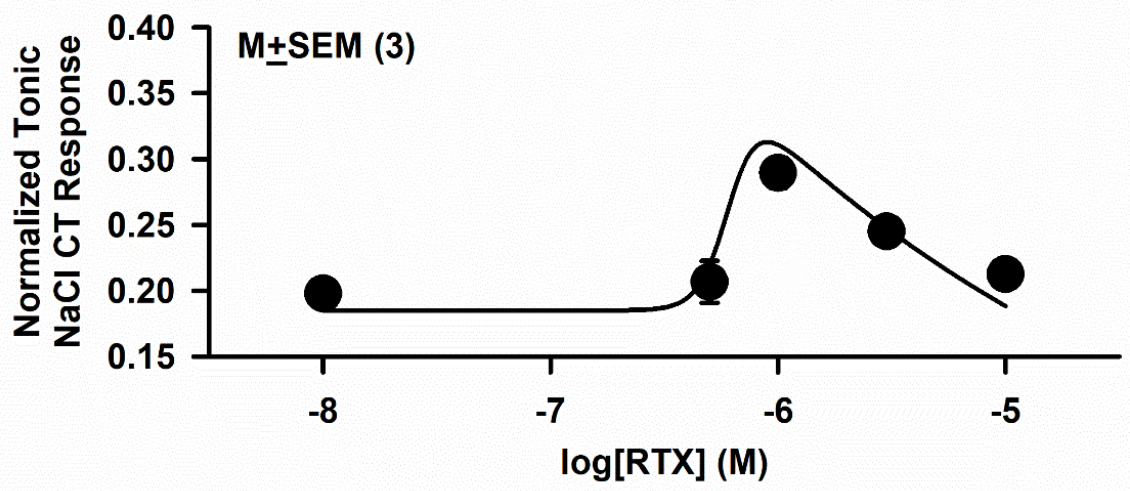

Figure 4. Effects of aromatic, neutral, acidic and basic $\mathrm{FII}_{\mathrm{m}}$ sub-fractions on the benzamil-insensitive $\mathrm{NaCl}$ chorda tympani (CT) response. (A) Shows the relationship between varying $\mathrm{FII}_{\mathrm{m}}$ sub-fraction concentrations expressed in log units and the mean normalized tonic $\mathrm{NaCl}$ CT response from 3 rats in each group for $\mathrm{FII}_{\mathrm{m}}(\bullet)$, aromatic $(\bigcirc)$ and combined neutral, acidic and basic maillard reacted peptides (A). (B) Shows the relationship between resiniferatoxin (RTX) concentrations expressed in log units and the mean normalized tonic $\mathrm{NaCl} C \mathrm{~T}$ responses from 3 rats $(\bullet)$. The values are $\mathrm{M} \pm \mathrm{SEM}$ of 3 rats in each group.

We also recorded $\mathrm{FII}_{\mathrm{m}}$-induced changes in the Bz-insensitive $\mathrm{NaCl} \mathrm{CT}$ response in wild type

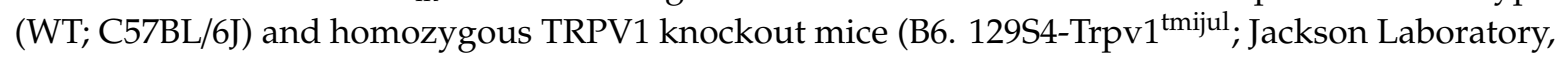
Bar Harbor, ME). Consistent with our earlier study with MRPs [27], FII $\mathrm{m}$ produced a similar biphasic response on the Bz-insensitive $\mathrm{NaCl} C \mathrm{C}$ response in $\mathrm{WT}$ mice. In TRPV1 $\mathrm{KO}$ mice, $\mathrm{FII}_{\mathrm{m}}(0.4 \%)$ did not induce $\mathrm{CT}$ response above the rinse baseline (data not shown). This is akin to our results in rats. $\mathrm{SB}$ inhibited the basal $\mathrm{Bz}$-insensitive $\mathrm{NaCl} \mathrm{CT}$ response. In the continuous presence of $\mathrm{SB}, \mathrm{FII}_{\mathrm{m}}$ produced a significantly smaller increase in the Bz-insensitive $\mathrm{NaCl} \mathrm{CT}$ response relative to the absence of SB (Figure 2). These results indicate that $\mathrm{FII}_{\mathrm{m}}$ produces similar effects on rats and mice.

\subsection{Effect of Calcitonin Gene Related Peptide (CGRP) on $\mathrm{NaCl} \mathrm{CT} \mathrm{Responses}$}

RTX activates and SB inhibits amiloride-insensitive $\mathrm{NaCl} C \mathrm{~T}$ responses (Figure 2). However, TRPV1 immunoreactivity was not found in TRCs [43-45]. We hypothesize that RTX and other modulators of TRPV1 alter Bz-insensitive $\mathrm{NaCl}$ CT responses indirectly, by releasing CGRP from trigeminal nerves [46]. The released CGRP then acts on its specific receptor (CGRPR) in TRCs to modulate Bz-insensitive $\mathrm{NaCl}$ CT responses [47]. 
Due to the concern that topical lingual application of CGRP, a large neuropeptide, may not be able to reach its receptor in TRCs, CGRP was administered by intraperitoneal injection. CT responses were monitored while the rat tongue was stimulated with $0.3 \mathrm{M} \mathrm{NH}_{4} \mathrm{Cl}, 0.3 \mathrm{M} \mathrm{NaCl}$ and $0.1 \mathrm{M} \mathrm{NaCl}$ before and after an i.p. injection of $23 \mu \mathrm{g} / 100 \mathrm{BW}$ or $68 \mu \mathrm{g} / 100 \mathrm{~g}$ BW CGRP dissolved in $0.5 \mathrm{~mL}$ PBS. Following i.p. injection of $68 \mu \mathrm{g} / 100 \mathrm{~g}$ BW CGRP the $\mathrm{NaCl} \mathrm{CT}$ response increased with time (data not shown). As shown in Figure 5A, 10 min post CGRP injection, the $\mathrm{NaCl}$ CT responses were almost two times greater than control (Figure 5B). CGRP also induced an increase in the CT response to $0.3 \mathrm{M}$ $\mathrm{NaCl}$. However, an i.p. injection of $23 \mu \mathrm{g} / 100 \mathrm{BW}$ CGRP did not induce any changes in rat $\mathrm{NaCl} \mathrm{CT}$ response $10 \mathrm{~min}$ post CGRP injection (Figure 5B). These results indicate that CGRP effects on $\mathrm{NaCl} C \mathrm{CT}$ response are both time- and dose-dependent and are observed over a range of $\mathrm{NaCl}$ concentrations. These results suggest a possible interaction between the trigeminal and salt taste systems.
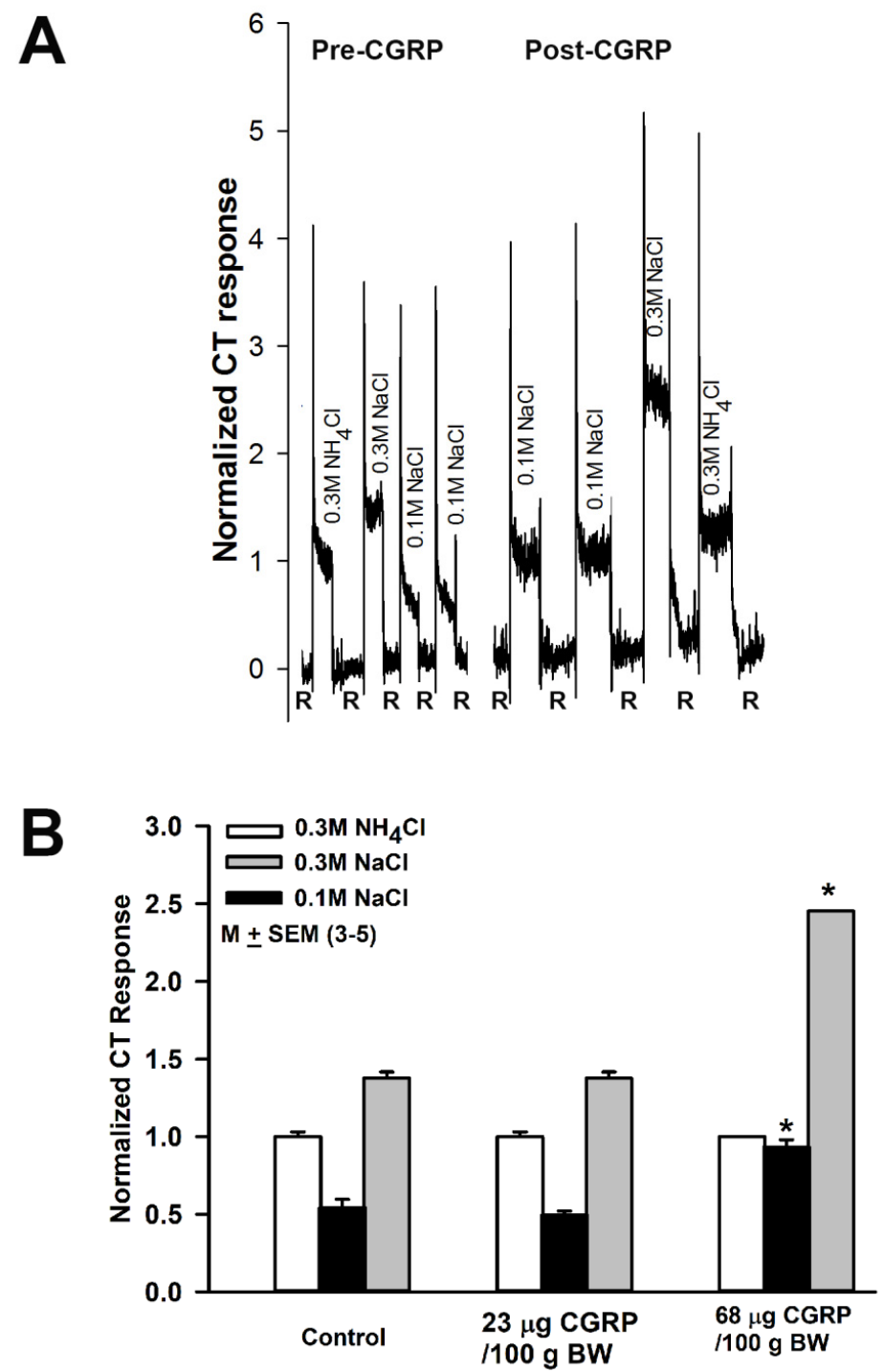

Figure 5. Effect of i.p. injection of calcitonin gene related peptide (CGRP) on $\mathrm{NaCl}$ chorda tympani (CT) response. (A) Shows a representative $\mathrm{CT}$ trace obtained while the rat tongue was first stimulated with rinse solution ( $\mathrm{R}$ ) and then with $0.3 \mathrm{M} \mathrm{NH}_{4} \mathrm{Cl}, 0.3 \mathrm{M} \mathrm{NaCl}$ and $0.1 \mathrm{M} \mathrm{NaCl}$ before and after i.p. injection of CGRP $(68 \mu \mathrm{g} / 100 \mathrm{~g}$ BW in PBS). In each rat the data were normalized to the tonic response obtained with $0.3 \mathrm{M} \mathrm{NH}_{4} \mathrm{Cl}$. The values are $\mathrm{M} \pm \mathrm{SEM}$ of 3 rats in each group. (B) Shows summary of the data from 3 rats in each group injected with either 23 or $68 \mu \mathrm{g} C G R P / 100 \mathrm{~g}$ BW. Values are $\mathrm{M} \pm \mathrm{SEM}$ of 3 rats. * $p=0.017(0.1 \mathrm{M} \mathrm{NaCl})$ and $0.009(0.3 \mathrm{M} \mathrm{NaCl})$. 
Using calcium imaging, a subset of acid responsive Type III mouse circumvallate TRCs were identified as the amiloride-insensitive salt responsive cells [2]. CGRPR has been suggested as the functional link to cellular transduction pathway for CGRP action on Type III TRCs. CGRP has been shown to increase $\left[\mathrm{Ca}^{2+}\right]$ in Type III TRCs. This effect of CGRP was dependent upon phospholipase $\mathrm{C}$ activation and was prevented by U73122 [47]. In mouse taste buds, CGRP caused TRCs to secrete serotonin (5-HT), a presynaptic (Type III) cell transmitter. 5-HT seems to reduce taste evoked ATP secretion in Type II cells [47]. However, at present this information is lacking in the fungiform taste receptive field.

Here, we present new data that suggest that CGRP can modulate rat amiloride-insensitive $\mathrm{NaCl}$ CT responses (Figure 5). In a recent study [3] amiloride-insensitive $\mathrm{Ca}^{2+}$ responses in mouse taste bud cells were localized to the apical tips of Type II, but not in Type III fungiform TRCs. It is suggested that, because anterior (fungiform) and posterior (circumvallate) taste fields differ functionally, in an earlier study [2] amiloride-insensitive $\mathrm{NaCl}$ responses may have been detected in only Type III circumvallate taste cells. Although the identity and location of the amiloride- and Bz-insensitive pathway(s) are ambiguous at present, $\mathrm{CT}$ recordings demonstrate that a component of the amiloride- and Bz-insensitive $\mathrm{NaCl} \mathrm{CT}$ response at low $\mathrm{NaCl}$ concentrations $(100 \mathrm{mM})$ is present in the anterior taste field that is modulated by RTX, FII $\mathrm{m}$, temperature, SB (Figures $1 \mathrm{~A}$ and $2 \mathrm{~B}$ ) and voltage [33,34].

$\mathrm{N}$-geranyl cyclopropylcarboxamide (NGCC), a modulator of the amiloride- and Bz-insensitive $\mathrm{NaCl}$ CT responses [48], activates hTRPV1 expressed in HEK293T cells [49]. In our preliminary studies, component of $\mathrm{FII}_{\mathrm{m}}$ induced inward current in TRPV1-expressing cells in whole-cell patch-clamp recordings [50,51]. Currently studies are underway to demonstrate direct activation of the expressed umami taste receptor by $\mathrm{FII}_{\mathrm{m}}$. However, at present it is not clear if, like RTX, other modulators of the amiloride-insensitive pathway release CGRP from TRPV1 expressed in trigeminal neurons in a dose-dependent manner. In addition, it is also not known if, like other modulators of the amiloride-insensitive $\mathrm{NaCl} \mathrm{CT}$ response, CGRP elicits a biphasic effect on rat $\mathrm{NaCl}$ CT responses. Taken together, our data suggest a possible linkage between the trigeminal system and amiloride-insensitive salt taste. It has recently been demonstrated that sour taste pathway works together with the somatosensory system to trigger aversive responses to acidic stimuli [5].

\subsection{Behavioral Studies with Mice}

Under control conditions, mice demonstrated a bell shaped $\mathrm{NaCl}$ preference curve with a significant preference for $100 \mathrm{mM} \mathrm{NaCl}$ (Figure $6 \mathrm{~A} ; \bigcirc$; ${ }^{*} p=0.02 ; n=10$ ) and aversion for $300 \mathrm{mM}$ $\mathrm{NaCl}\left({ }^{* * * *} p=0.0001\right)$ [39]. In the presence of $10 \mu \mathrm{M}$ amiloride the $\mathrm{NaCl}$ preference curve was again biphasic but was shifted to the right on the $\mathrm{NaCl}$ concentration axis. In the presence of amiloride, mice showed a significant $\mathrm{NaCl}$ preference at $150 \mathrm{mM} \mathrm{NaCl}$ (Figure $6 \mathrm{~A} ; \bullet$; ${ }^{* * *} p=0.0024$ ). 
A
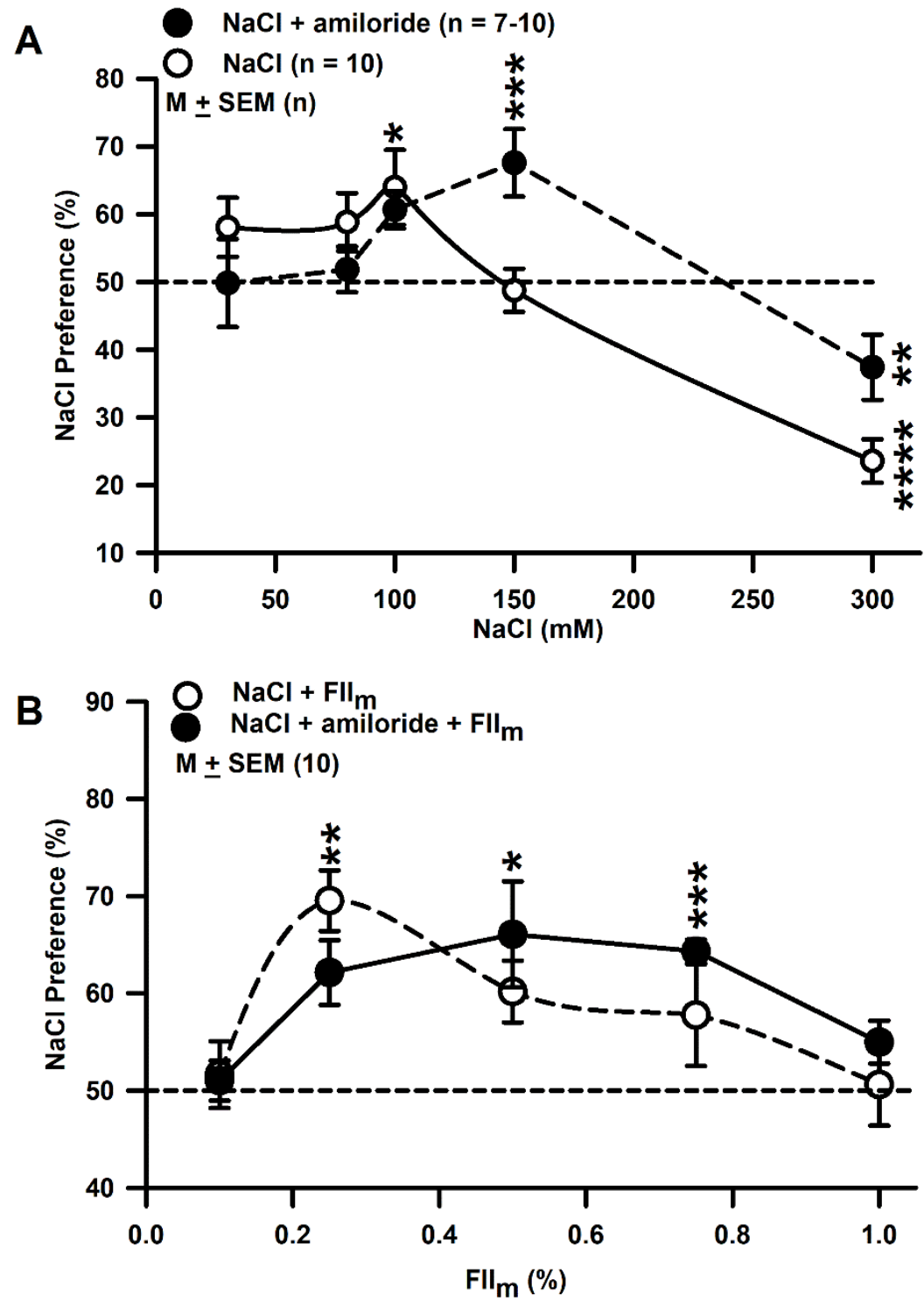

Figure 6. Effect of amiloride and $\mathrm{FII}_{\mathrm{m}}$ on $\mathrm{NaCl}$ Preference in WT mice. (A) Shows $\mathrm{NaCl}$ Preference in WT mice when given a choice between $\mathrm{H}_{2} \mathrm{O}$ and varying concentrations of $\mathrm{NaCl}(3,80,100,120,150$, 200 and $300 \mathrm{mM})$ in the absence $(\bigcirc)$ and presence of $10 \mu \mathrm{M}$ amiloride $(\bullet)$. The values are presented as mean $(\mathrm{M}) \pm \mathrm{SEM}$ of $n$, where $n=7-10$. ${ }^{*} p=0.02 ;{ }^{* *} p=0.0134 ;{ }^{* * *} p=0.0024 ;{ }^{* * * *} p=0.0001$. (B) Shows $\mathrm{NaCl}$ Preference in WT mice when given a choice between $\mathrm{H}_{2} \mathrm{O}$ and $100 \mathrm{mM} \mathrm{NaCl}(\bigcirc)$ or $\mathrm{H}_{2} \mathrm{O}$ and 100 $\mathrm{mM} \mathrm{NaCl}+10 \mu \mathrm{M}$ amiloride $(\bullet)$ containing increasing concentrations of $\mathrm{FII}_{\mathrm{m}}(0.1$ to $1 \%){ }^{*} p=0.0086$; ** $p=0.0018 ;{ }^{* * *} p=0.0001(n=10)$. Dotted line represents the indifference value.

As shown in Figure $6 \mathrm{~B}$, adding increasing concentrations of $\mathrm{FII}_{\mathrm{m}}(0.1$ to $1 \%)$ to $100 \mathrm{mM} \mathrm{NaCl}$ solutions in the absence and presence of $10 \mu \mathrm{M}$ amiloride produced biphasic changes in $\mathrm{NaCl}$ preference, increasing it at $0.25 \%$ and lowering it at higher concentrations. Under control conditions, FII $_{\mathrm{m}}$ maximally enhanced the $\mathrm{NaCl}$ preference at $0.25 \%$ relative to $\mathrm{NaCl}$ alone (Figure $6 \mathrm{~B} ; \bigcirc^{* *} p=0.0001 ; n=10$ ). Above $0.25 \% \mathrm{FII}_{\mathrm{m}} \mathrm{NaCl}$ preference was significantly less than its maximum value. In the presence of $10 \mu \mathrm{M}$ amiloride the maximum increase in $\mathrm{NaCl}$ preference was observed at $0.5 \% \mathrm{FII}_{\mathrm{m}}$ (Figure 6B; • ; ${ }^{*} p=0.0086$ ). Above $0.5 \% \mathrm{FII}_{\mathrm{m}} \mathrm{NaCl}$ preference was significantly less than its maximum value. There was no change in $\mathrm{NaCl}$ preference when equivalent concentrations of the $\mathrm{FII}_{\mathrm{im}}$ were added to the test solutions containing $100 \mathrm{mM} \mathrm{NaCl}$ or $100 \mathrm{mM} \mathrm{NaCl}+10 \mu \mathrm{M}$ amiloride (data not shown). These behavioral responses to $\mathrm{NaCl}$ are correlated with the biphasic effects of $\mathrm{FII}_{\mathrm{m}}$ concentrations on the 
amiloride- and Bz-insensitive $\mathrm{NaCl} \mathrm{CT}$ responses (Figure 1). In this sense, $\mathrm{FII}_{\mathrm{m}}$ mimics the effect of other modulators $[27,33,34,36,48,52]$ of the amiloride- and Bz-insensitive $\mathrm{NaCl}$ CT responses.

\subsection{Effect of FII $m$ on Salt Taste in Human}

In human sensory evaluation, $\mathrm{FII}_{\mathrm{m}}$ produced a biphasic effect on salt taste. $\mathrm{FII}_{\mathrm{m}}$ increased salt taste intensity between 0.3 and $0.5 \%$, but slightly decreased it above $0.5 \%$ (Figure 7 ). The maximum salt taste intensity in human subjects was detected at $0.5 \% \mathrm{FII}_{\mathrm{m}}$ (Figure $\left.7 ; \bullet \bullet\right)$. In contrast, $\mathrm{FII}_{\mathrm{im}}$ had no significant effect on human salt taste perception (Figure 7; $\bigcirc$ ). In our previous studies, GalA-MRPs, Xyl-MRPs [27] and NGCC [48], modulators of the amiloride- and Bz-insensitive $\mathrm{NaCl}$ CT responses in rodents, also produced biphasic effects on human salt taste intensity. Although functional ENaC channels are expressed in human fungiform TRCs [53], the amiloride- and Bz-insensitive salt taste receptors are the predominant transducers of salt taste in humans [25-27]. Thus, modulation of the amiloride-insensitive salt taste in humans via $\mathrm{FII}_{\mathrm{m}}$ or other modulators may provide alternate ways to regulated human salt taste and perhaps salt intake.

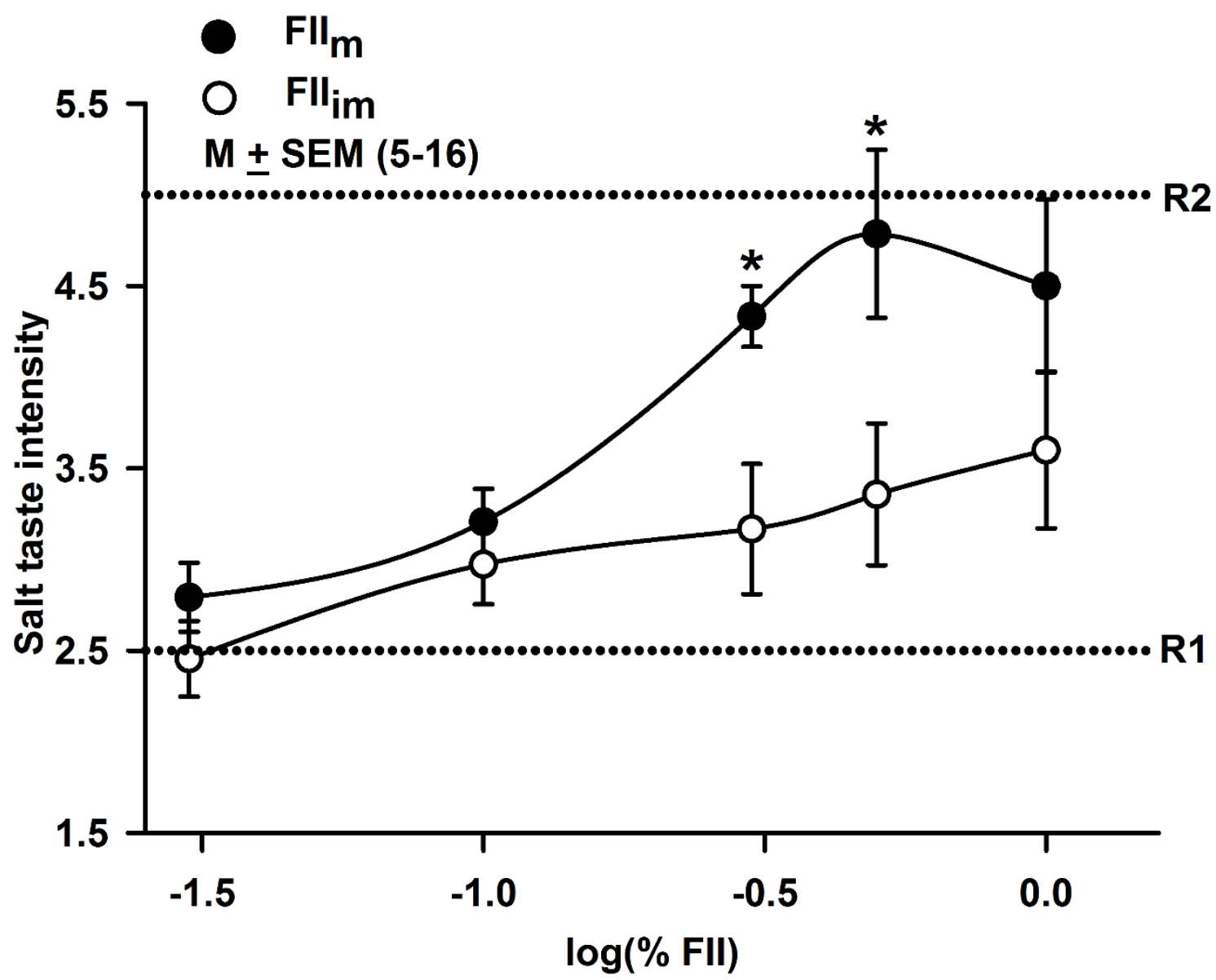

Figure 7. Effect of $\mathrm{FII}_{\mathrm{m}}$ and $\mathrm{FII}_{\mathrm{im}}$ on human salt taste intensity. Shows the effect of varying concentrations $\left(0.03\right.$ and $1.0 \%$ ) of $\mathrm{FII}_{\mathrm{im}}(\bigcirc)$ and $\mathrm{FII}_{\mathrm{m}}(\bullet)$ expressed in log units on human salt taste intensity. R1 corresponds to the intensity (2.5) of $0.2 \% \mathrm{NaCl}$ and $\mathrm{R} 2$ corresponds to the intensity (5.0) of $0.35 \% \mathrm{NaCl}$. $\mathrm{FII}_{\mathrm{m}}$ showed a significant $\left({ }^{*} p=0.01\right)$ salt taste-enhancing activity at $0.003 \%$ and $0.005 \%$. In contrast, no effect of FII $_{\mathrm{im}}$ was observed on human salt taste intensity over the concentration range between 0.03 and $1.0 \%$.

\subsection{Effect of FII $m$ on the Rat CT Response to Glutamate}

Stimulating the rat tongue with $100 \mathrm{mM} \mathrm{MSG}+\mathrm{Bz}+\mathrm{SB}$ elicited a CT response and the CT response was enhanced in the presence of $1 \mathrm{mM} \mathrm{IMP} \mathrm{(Figure} 8 \mathrm{~A}$ ). Glutamate CT response was also enhanced in 
the presence of $2.5 \% \mathrm{FII}_{\mathrm{m}}$. The normalized tonic $\mathrm{CT}$ responses to glutamate in the absence and presence of IMP and $\mathrm{FII}_{\mathrm{m}}$ are summarized in Figure $8 \mathrm{~B}$. $\mathrm{FII}_{\mathrm{m}}$ at $2.5 \%$ enhanced the $\mathrm{CT}$ response to glutamate that was equivalent to the enhancement observed with $1 \mathrm{mM}$ IMP. These results further suggest that unlike the Bz-insensitive $\mathrm{NaCl} C \mathrm{CT}$ response, the basal umami CT response and the subsequent $\mathrm{FII}_{\mathrm{m}}$ induced enhancement of the umami CT response is SB-insensitive. In our previous study, Xyl-MRs also enhanced the CT response to glutamate at concentrations above which they modulated the $\mathrm{NaCl}+$ Bz CT responses. In contrast to Xyl-MRPs, at these concentrations GalA-MRPs or Glc-NH$-\mathrm{NH}_{2}-\mathrm{MRs}$ did not show effects on the glutamate $\mathrm{CT}$ response [27]. These results suggest that the umami enhancing effect of MRPs is dependent on the conjugated sugar(s). However, at present the identity of the specific sugar resides conjugated with the peptides comprising the $\mathrm{FII}_{\mathrm{m}}$ is not known.
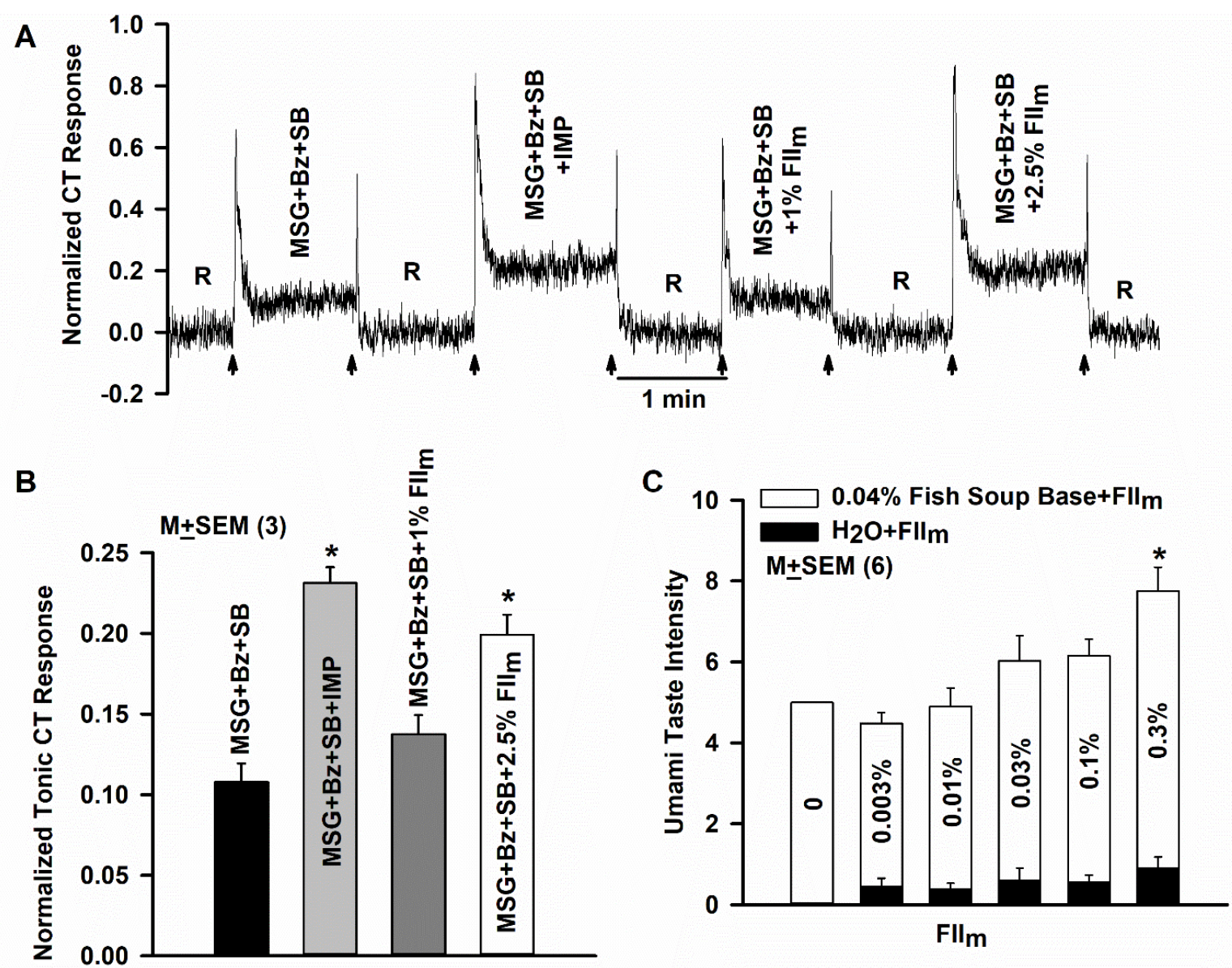

Figure 8. Effect of $\mathrm{FII}_{\mathrm{m}}$ on the glutamate chorda tympani (CT) response and human umami taste sensory evaluation. (A) Shows a representative CT response in which the rat tongue was first rinsed with the rinse solution (R) and then with $100 \mathrm{mM}$ MSG $+5 \mu \mathrm{M}$ benzamil (Bz) $+1 \mu \mathrm{M}$ SB-366791 (SB), $\mathrm{MSG}+\mathrm{Bz}+\mathrm{SB}+1 \mathrm{mM}$ IMP, $\mathrm{MSG}+\mathrm{Bz}+\mathrm{SB}+1 \% \mathrm{FII}_{\mathrm{m}}$ and $\mathrm{MSG}+\mathrm{Bz}+\mathrm{SB}+2.5 \% \mathrm{FII}_{\mathrm{m}}$. The arrows represent the time period when the tongue was superfused with the rinse and stimulating solutions. (B) Shows mean normalized tonic CT responses from 3 rats. In each rat the data were normalized to the tonic response obtained with $0.3 \mathrm{M} \mathrm{NH}_{4} \mathrm{Cl} .{ }^{*} p=0.001$. (C) Shows the effect of adding increasing concentrations of $\mathrm{FII}_{\mathrm{m}}\left(0.003\right.$ to $0.3 \%$ ) to the $0.04 \%$ Fish Soup Base (open bars) or to $\mathrm{H}_{2} \mathrm{O}$ (filled bars). The values are presented as $\mathrm{M} \pm \mathrm{SEM}$ of $\mathrm{n}$, where $\mathrm{n}$ represents the number of panel members tested. * $p=0.01$.

In our earlier study [33], RTX demonstrated a biphasic response on the rat Bz-insensitive $\mathrm{NaCl}$ CT response. At $1 \mu \mathrm{M}$, it maximally enhanced and at $10 \mu \mathrm{M}$, maximally inhibited the Bz-insensitive $\mathrm{NaCl} \mathrm{CT}$ response. At 1 and $10 \mu \mathrm{M}$ concentrations, RTX did not alter CT responses to $500 \mathrm{mM}$ sucrose, 
$10 \mathrm{mM}$ quinine and $10 \mathrm{mM} \mathrm{HCl}$. These results tend to suggest that over the concentration range that alter the $\mathrm{Bz}$ - insensitive $\mathrm{NaCl}$ CT response, modulators of the amiloride-insensitive pathway may not alter sweet, bitter or sour taste. At present it is not known if $\mathrm{FII}_{\mathrm{m}}$ concentrations that modulate salt responses also alter responses to other taste stimuli.

\subsection{Effect of FII $I_{m}$ on Umami Taste in Human}

In human subjects, adding $0.3 \% \mathrm{FII}_{\mathrm{m}}$ to umami soup base produced a significant increase in umami taste intensity (Figure $8 \mathrm{C}$; open bars; $p<0.01 ; n=9$ ). Equivalent concentrations of $\mathrm{FII}_{\mathrm{m}}$ added to water produced umami intensity ratings of $<1$ (Figure $8 \mathrm{C}$; filled bars). In contrast to a strong salt taste enhancing effect at $0.5 \% \mathrm{FII}_{\mathrm{m}}$, lower concentrations $(<0.3 \%)$ of the $\mathrm{FII}_{\mathrm{m}}$ did not have a significant effect on umami taste intensity. Thus, depending upon the concentration, MRPs can be used either as salt taste or umami taste modifiers.

These results show that $\mathrm{FII}_{\mathrm{m}}$ modulates both salt and umami taste in humans but at different concentration range. The differences in the sensitivity to $\mathrm{FII}_{\mathrm{m}}$ between humans and mice are most likely due to the variations in the umami taste receptor protein $[54,55]$. This dual property of being able to modulate the $\mathrm{Bz}$-insensitive $\mathrm{NaCl}$ response and the glutamate response at two different concentration ranges is not restricted to $\mathrm{FII}_{\mathrm{m}}$. We have recently shown that at different concentrations ranges, NGCC modulates Bz-insensitive salt taste responses and glutamate taste responses in humans and animal models [48].

\section{Conclusions}

In summary, a naturally occurring kokumi taste active peptide fraction (MW 500-10,000 Da) isolated from mature ( $\mathrm{FII}_{\mathrm{m}}$; 4-year old) Ganjang, a typical Korean Soy Sauce, modulates the amiloride-, Bz-insensitive $\mathrm{NaCl}$ CT response in rodents in a biphasic manner. At low concentrations $(0.1$ to $0.5 \%)$ it enhanced and at higher concentrations $(>0.5 \%)$ inhibited the Bz-insensitive $\mathrm{NaCl} C \mathrm{~T}$ response. $\mathrm{FII}_{\mathrm{m}}$ effects on Bz-insensitive $\mathrm{NaCl} \mathrm{CT}$ responses are TRPV1 dependent. $\mathrm{FII}_{\mathrm{m}}$ may indirectly alter $\mathrm{CT}$ responses to $\mathrm{NaCl}$ via the release of CGRP from trigeminal fibers near the fungiform taste buds in the anterior taste field. This suggests a novel relationship between trigeminal system and salt taste perception. At concentrations $>1 \%, \mathrm{FII}_{\mathrm{m}}$ enhanced the $\mathrm{CT}$ response to glutamate. In human sensory tests, $\mathrm{FII}_{\mathrm{m}}$ increased the salt taste intensity between 0.3 and $0.5 \%$, and the umami taste intensity at $0.3 \%$. We conclude that, depending upon its concentration, $\mathrm{FII}_{\mathrm{m}}$ modulates both salty and umami tastes in humans and rodents. The active component(s) and salt enhancing property of naturally occurring MRPs by longer maturation in food should be further investigated for a better understanding of the potential link between the compound and its beneficial effect in reducing salt intake in the human population.

Author Contributions: Conceptualization, M.-R.R. and V.L.; methodology, E.-Y.K., S.M.; validation, E.-Y.K.; formal analysis, A.-Y.S., H.-J.S., J.Q; investigation, A.-Y.S., H.-J.S., S.M., J.Q.; data curation, Y.K.; writing-original draft preparation, M.-R.R. and V.L.; writing-review and editing, M.-R.R. and V.L..; funding acquisition, M.-R.R., V.L. and J.R.G. All authors have read and agreed to the published version of the manuscript.

Funding: This research was funded by Korea Food Research Institute, grant numbers E069002 and E0131201, the National Research Foundation of Korea (NRF), grant number NRF2020R1A2C2004661, National Institute of Health, grant numbers DK34153 (J.R.G.), DC-005981 (V.L.), and DC-011569 (V.L.), VCU Wright Center for Clinical and Translational Research 2019 and VCU Health under the Value and Efficiency Teaching and Research program 2019 (V.L.). The APC was funded by NRF.

Acknowledgments: We gratefully acknowledge the assistance of MJ Kim of Korea Food Research Institute.

Conflicts of Interest: The authors declare no conflict of interest. The funders had no role in the design of the study; in the collection, analyses, or interpretation of data; in the writing of the manuscript, or in the decision to publish the results. 


\section{References}

1. Yarmolinsky, D.A.; Zuker, C.S.; Ryba, N.J. Common sense about taste: From mammals to insects. Cell 2009, 139, 234-244. [CrossRef] [PubMed]

2. Lewandowski, B.C.; Sukumaran, S.K.; Margolskee, R.F.; Bachmanov, A.A. Amiloride-Insensitive Salt Taste Is Mediated by Two Populations of Type III Taste Cells with Distinct Transduction Mechanisms. J. Neurosci. 2016, 36, 1942-1953. [CrossRef] [PubMed]

3. Roebber, J.K.; Roper, S.D.; Chaudhari, N. The Role of the Anion in Salt (NaCl) Detection by Mouse Taste Buds. J. Neurosci. 2019, 39, 6224-6232. [CrossRef] [PubMed]

4. Nomura, K.; Nakanishi, M.; Ishidate, F.; Iwata, K.; Taruno, A. All-Electrical Ca ${ }^{2+}$-Independent Signal Transduction Mediates Attractive Sodium Taste in Taste Buds. Neuron 2020, 106, 1-14. [CrossRef]

5. Zhang, J.; Jin, H.; Zhang, W.; Ding, C.; O'Keeffe, S.; Ye, M.; Zuker, C.S. Sour Sensing from the Tongue to the Brain. Cell 2019, 179, 392-402. [CrossRef]

6. Teng, B.; Wilson, C.E.; Tu, Y.H.; Joshi, N.R.; Kinnamon, S.C.; Liman, E.R. Cellular and Neural Responses to Sour Stimuli Require the Proton Channel Otop1. Curr. Biol. 2019, 29, 3647-3656. [CrossRef]

7. Keast, S.J.R.; Breslin, P.A.S. An overview of binary taste-taste interactions. Food Qual. Prefer. 2003, 14, 111-124. [CrossRef]

8. Roper, S.D.; Chaudhari, N. Taste buds: Cells, signals and synapses. Nat. Rev. Neurosci. 2017, 18, $485-497$. [CrossRef]

9. Yamaguchi, S. Basic properties of umami and effects on humans. Physiol. Behav. 1991, 49, 833-841. [CrossRef]

10. Zhang, F.; Klebansky, B.; Fine, R.M.; Xu, H.; Pronin, A.; Liu, H.; Tachdjian, C.; Li, X. Molecular mechanism for the umami taste synergism. Proc. Natl. Acad. Sci. USA 2008, 105, 20930-20934. [CrossRef]

11. Kim, M.J.; Son, H.J.; Kim, Y.; Misaka, T.; Rhyu, M.R. Umami-bitter interactions: The suppression of bitterness by umami peptides via human bitter taste receptor. Biochem. Biophys. Res. Commun. 2015, 456, 586-590. [CrossRef]

12. Servant, G.; Tachdjian, C.; Tang, X.Q.; Werner, S.; Zhang, F.; Li, X.; Kamdar, P.; Petrovic, G.; Ditschun, T.; Java, A.; et al. Positive allosteric modulators of the human sweet taste receptor enhance sweet taste. Proc. Natl. Acad. Sci. USA 2010, 107, 4746-4751. [CrossRef] [PubMed]

13. DuBois, G.E.; Prakash, I. Non-caloric sweeteners, sweetness modulators, and sweetener enhancers. Annu. Rev. Food Sci. Technol. 2012, 3, 353-380. [CrossRef] [PubMed]

14. Ueda, Y.; Sakaguchi, M.; Hirayama, K.; Miyajima, R.; Kimizuka, A. Characteristic Flavor Constituents in Water Extract of Garlic. Agric. Biol. Chem. 1990, 54, 163-169.

15. Maruyama, Y.; Yasuda, R.; Kuroda, M.; Eto, Y. Kokumi substances, enhancers of basic tastes, induce responses in calcium-sensing receptor expressing taste cells. PLoS ONE 2012, 7, e34489. [CrossRef] [PubMed]

16. Ueda, Y.; Tsubuku, T.; Miyajima, R. Composition of Sulfur-Containing Components in Onion and Their Flavor Characters. Biosci. Biotechnol. Biochem. 1994, 58, 108-110. [CrossRef] [PubMed]

17. Ueda, Y.; Yonemitsu, M.; Tsubuku, T.; Sakaguchi, M.; Miyajima, R. Flavor characteristics of glutathione in raw and cooked foodstuffs. Biosci. Biotechnol. Biochem. 1997, 61, 1977-1980. [CrossRef]

18. Wang, M.; Yao, Y.; Kuang, D.; Hampson, D.R. Activation of family C G-protein-coupled receptors by the tripeptide glutathione. J. Biol. Chem. 2006, 281, 8864-8870. [CrossRef]

19. Ohsu, T.; Amino, Y.; Nagasaki, H.; Yamanaka, T.; Takeshita, S.; Hatanaka, T.; Maruyama, Y.; Miyamura, N.; Eto, Y. Involvement of the calcium-sensing receptor in human taste perception. J. Biol. Chem. 2010, 285, 1016-1022. [CrossRef]

20. Maillard, L.C. Réaction de Maillard. Action des acides aminés sur les sucres: Formation des mélanoïdines par voie méthodique. Compte-Rendu De L'académie Des. Sci. 1912, 154, 66-68.

21. Rhyu, M.R.; Kim, E.Y.; Ogasawara, M.; Nakahisaki, H. Maillard peptides are a clue to the Kokumi taste of a typical Korean soy sauce, Ganjang. In Proceedings of the Association for Chemoreception Sciences, Sarasota, FL, USA, 13-17 April 2005.

22. DeSimone, J.; Lyall, V. Amiloride-Sensitive Ion Channels. In The Senses: A Comprehensive Reference; Basbaum, A., Kaneko, A., Shepherd, G., Westheimer, G., Stuart, F., Gary, B., Eds.; Olfaction \& Taste; Academic Press: San Diego, CA, USA, 2008; Volume 4, pp. 281-288.

23. Chandrashekar, J.; Kuhn, C.; Oka, Y.; Yarmolinsky, D.A.; Hummler, E.; Ryba, N.J.; Zuker, C.S. The cells and peripheral representation of sodium taste in mice. Nature 2010, 464, 297-301. [CrossRef] [PubMed] 
24. Lin, W.; Finger, T.E.; Rossier, B.C.; Kinnamon, S.C. Epithelial Na+ channel subunits in rat taste cells: Localization and regulation by aldosterone. J. Comp. Neurol. 1999, 405, 406-420. [CrossRef]

25. Ossebaard, C.A.; Smith, D.V. Effect of amiloride on the taste of $\mathrm{NaCl}$, Na-gluconate and $\mathrm{KCl}$ in humans: Implications for $\mathrm{Na}+$ receptor mechanisms. Chem. Senses 1995, 20, 37-46. [CrossRef] [PubMed]

26. Feldman, G.M.; Mogyorosi, A.; Heck, G.L.; DeSimone, J.A.; Santos, C.R.; Clary, R.A.; Lyall, V. Salt-evoked lingual surface potential in humans. J. Neurophysiol. 2003, 90, 2060-2064. [CrossRef] [PubMed]

27. Katsumata, T.; Nakakuki, H.; Tokunaga, C.; Fujii, N.; Egi, M.; Phan, T.H.; Mummalaneni, S.; DeSimone, J.A.; Lyall, V. Effect of Maillard reacted peptides on human salt taste and the amiloride-insensitive salt taste receptor (TRPV1t). Chem. Senses 2008, 33, 665-680. [CrossRef] [PubMed]

28. Ogasawara, M.; Katsumata, T.; Egi, M. Taste properties of Maillard-reaction products prepared from 1000 to 5000 Da peptide. Food Chem. 2006, 99, 600-604. [CrossRef]

29. Coleman, J.; Williams, A.; Phan, T.H.; Mummalaneni, S.; Melone, P.; Ren, Z.; Zhou, H.; Mahavadi, S.; Murthy, K.S.; Katsumata, T.; et al. Strain differences in the neural, behavioral, and molecular correlates of sweet and salty taste in naive, ethanol- and sucrose-exposed P and NP rats. J. Neurophysiol. 2011, 106, 2606-2621. [CrossRef]

30. Fujimaki, M.; Arai, S.; Yamashita, M.; Kato, H.; Noguchi, M. Taste Peptide Fractionation from a Fish Protein Hydrolysate. Agric. Biol. Chem. 1973, 37, 2891-2898. [CrossRef]

31. Rhyu, M.R.; Song, A.Y.; Kim, H.Y.; Kim, S.S.; Tokunaga, C.; Phan, T.-H.T.; Heck, G.L.; DeSimone, J.A.; Lyall, V. Naturally occurring peptides in mature Korean Soy Sauce modulate TRPV1 Variant Salt Taste Receptor. In Proceedings of the Association for Chemoreception Sciences, St. Petersburg, FL, USA, 13-17 April 2011.

32. DeSimone, J.A.; Lyall, V.; Heck, G.L.; Phan, T.H.; Alam, R.I.; Feldman, G.M.; Buch, R.M. A novel pharmacological probe links the amiloride-insensitive $\mathrm{NaCl}, \mathrm{KCl}$, and $\mathrm{NH}(4) \mathrm{Cl}$ chorda tympani taste responses. J. Neurophysiol. 2001, 86, 2638-2641. [CrossRef]

33. Lyall, V.; Heck, G.L.; Vinnikova, A.K.; Ghosh, S.; Phan, T.H.; Alam, R.I.; Russell, O.F.; Malik, S.A.; Bigbee, J.W.; DeSimone, J.A. The mammalian amiloride-insensitive non-specific salt taste receptor is a vanilloid receptor-1 variant. J. Physiol. 2004, 558, 147-159. [CrossRef]

34. Lyall, V.; Heck, G.L.; Vinnikova, A.K.; Ghosh, S.; Phan, T.H.; Desimone, J.A. A novel vanilloid receptor-1 (VR-1) variant mammalian salt taste receptor. Chem. Senses 2005, 30 (Suppl. 1), i42-i43. [CrossRef] [PubMed]

35. Lyall, V.; Heck, G.L.; Phan, T.H.; Mummalaneni, S.; Malik, S.A.; Vinnikova, A.K.; Desimone, J.A. Ethanol modulates the VR-1 variant amiloride-insensitive salt taste receptor. II. Effect on chorda tympani salt responses. J. Gen. Physiol. 2005, 125, 587-600. [CrossRef]

36. Lyall, V.; Phan, T.H.; Mummalaneni, S.; Mansouri, M.; Heck, G.L.; Kobal, G.; DeSimone, J.A. Effect of nicotine on chorda tympani responses to salty and sour stimuli. J. Neurophysiol. 2007, 98, 1662-1674. [CrossRef]

37. Yamaguchi, S. The Synergistic Taste Effect of Monosodium Glutamate and Disodium 5'-Inosinate. J. Food Sci. 2006, 32, 473-478. [CrossRef]

38. Gunthorpe, M.J.; Rami, H.K.; Jerman, J.C.; Smart, D.; Gill, C.H.; Soffin, E.M.; Luis Hannan, S.; Lappin, S.C.; Egerton, J.; Smith, G.D.; et al. Identification and characterisation of SB-366791, a potent and selective vanilloid receptor (VR1/TRPV1) antagonist. Neuropharmacology 2004, 46, 133-149. [CrossRef]

39. Bachmanov, A.A.; Tordoff, M.G.; Beauchamp, G.K. Voluntary sodium chloride consumption by mice: Differences among five inbred strains. Behav. Genet. 1998, 28, 117-124. [CrossRef] [PubMed]

40. Meilgaard, M.; Civille, G.V.; Carr, B.T. Descriptive analysis Techniques. In Sensory Evaluation Techniques, 2nd ed.; Meilgaard, M., Civille, G.V., Carr, B.T., Eds.; CRC Press: Boca Raton, FL, USA, 1988; pp. 119-142.

41. Lyall, V.; Phan, T.H.; Mummalaneni, S.; Melone, P.; Mahavadi, S.; Murthy, K.S.; DeSimone, J.A. Regulation of the benzamil-insensitive salt taste receptor by intracellular $\mathrm{Ca}+$, protein kinase $\mathrm{C}$, and calcineurin. J. Neurophysiol. 2009, 102, 1591-1605. [CrossRef] [PubMed]

42. Lyall, V.; Phan, T.H.; Ren, Z.; Mummalaneni, S.; Melone, P.; Mahavadi, S.; Murthy, K.S.; DeSimone, J.A. Regulation of the putative TRPV1t salt taste receptor by phosphatidylinositol 4,5-bisphosphate. J. Neurophysiol. 2010, 103, 1337-1349. [CrossRef]

43. Gu, X.F.; Lee, J.H.; Yoo, S.B.; Moon, Y.W.; Jahng, J.W. Intra-oral pre-treatment with capsaicin increases consumption of sweet solutions in rats. Nutr. Neurosci. 2009, 12, 149-154. [CrossRef]

44. Moon, Y.W.; Lee, J.H.; Yoo, S.B.; Jahng, J.W. Capsaicin receptors are colocalized with sweet/bitter receptors in the taste sensing cells of circumvallate papillae. Genes Nutr. 2010, 5, 251-255. [CrossRef] 
45. Simon, S.A.; Gutierrez, R. TRP channels at the periphery of the taste and trigeminal systems, Chapter 7. In Neurobiology of TRP Channels, 2nd ed.; CRC Press: Boca Raton, FL, USA; Taylor \& Francis: Abingdon, UK, 2017.

46. Kawashima, M.; Imura, K.; Sato, I. Topographical organization of TRPV1-immunoreactive epithelium and CGRP-immunoreactive nerve terminals in rodent tongue. Eur. J. Histochem. 2012, 56, e21. [CrossRef] [PubMed]

47. Huang, A.Y.; Wu, S.Y. Calcitonin Gene-Related Peptide Reduces Taste-Evoked ATP Secretion from Mouse Taste Buds. J. Neurosci. 2015, 35, 12714-12724. [CrossRef] [PubMed]

48. Dewis, M.L.; Phan, T.H.; Ren, Z.; Meng, X.; Cui, M.; Mummalaneni, S.; Rhyu, M.R.; DeSimone, J.A.; Lyall, V. $\mathrm{N}$-geranyl cyclopropyl-carboximide modulates salty and umami taste in humans and animal models. J. Neurophysiol. 2013, 109, 1078-1090. [CrossRef] [PubMed]

49. Kim, M.J.; Son, H.J.; Kim, Y.; Kweon, H.J.; Suh, B.C.; Lyall, V.; Rhyu, M.R. Selective activation of hTRPV1 by N-geranyl cyclopropylcarboxamide, an amiloride-insensitive salt taste enhancer. PLoS ONE 2014, 9, e89062. [CrossRef]

50. Rhyu, M.R.; Lee, B.H.; Kim, Y.H.; Song, A.Y.; Son, H.J.; Oh, S.B.; Lyall, V.; Kim, E.Y. Soy-derived glycopeptides induce inward current in TRPV1-expressing cells by whole-cell patch-clamp recording. In Proceedings of the Association for Chemoreception Sciences, Sarasota, FL, USA, 25-29 April 2007.

51. Rhyu, M.-R.; Song, A.-Y.; Kim, E.-Y.; Oh, S.B.; Lee, Y.; Lim, W.C. Pharmaceutical Composition for Preventing/Treating TRPV1 Activity-Related and Inflammation-Related Diseases or Conditions Containing Maillard peptide Separated from well-Aged Traditional Soy Sauce as Active Ingredient. U.S. Patent No. 8,653,032 B2, 18 February 2014.

52. Treesukosol, Y.; Lyall, V.; Heck, G.L.; DeSimone, J.A.; Spector, A.C. A psychophysical and electrophysiological analysis of salt taste in Trpv1 null mice. Am. J. Physiol. Regul. Integr. Comp. Physiol. 2007, 292, R1799-R1809. [CrossRef]

53. Xu, J.J.; Elkaddi, N.; Garcia-Blanco, A.; Spielman, A.I.; Bachmanov, A.A.; Chung, H.Y.; Ozdener, M.H. Arginyl dipeptides increase the frequency of $\mathrm{NaCl}$-elicited responses via epithelial sodium channel alpha and delta subunits in cultured human fungiform taste papillae cells. Sci. Rep. 2017, 7, 7483. [CrossRef]

54. Shigemura, N.; Shirosaki, S.; Ohkuri, T.; Sanematsu, K.; Islam, A.A.; Ogiwara, Y.; Kawai, M.; Yoshida, R.; Ninomiya, Y. Variation in umami perception and in candidate genes for the umami receptor in mice and humans. Am. J. Clin. Nutr. 2009, 90, 764s-769s. [CrossRef]

55. Shigemura, N.; Shirosaki, S.; Sanematsu, K.; Yoshida, R.; Ninomiya, Y. Genetic and molecular basis of individual differences in human umami taste perception. PLOS ONE 2009, 4, e6717. [CrossRef] 